UNIVERSIDADE FEDERAL DO RIO GRANDE

PROGRAMA DE PÓS-GRADUAÇÃO EM EDUCAÇÃO AMBIENTAL MESTRADO EM EDUCAÇÃO AMBIENTAL

PABLO VIANA STOLZ

A COMPREENSÃO DOS SEPARADORES DE RESÍDUOS SÓLIDOS EM RELAÇÃO AO SEU TRABALHO, SAÚDE E AMBIENTE

Rio Grande 
PABLO VIANA STOLZ

\section{A COMPREENSÃO DOS SEPARADORES DE RESÍDUOS SÓLIDOS EM RELAÇÃO AO SEU TRABALHO, SAÚDE E AMBIENTE}

Dissertação de Mestrado apresentada ao Programa de Pós-Graduação em Educação Ambiental da Universidade Federal do Rio Grande como parte dos requisitos para obtenção do grau de Mestre em Educação Ambiental.

Orientadora: Professora Phd. Marta Regina César Vaz

Rio Grande 
S876c Stolz, Pablo Viana

A compreensão dos separadores de resíduos sólidos em relação ao seu trabalho, saúde e ambiente / Pablo Viana Stolz ; orientação da Profa. Phd Marta Regina César Vaz. 2008 .

91f.

Dissertação (Mestrado) - Universidade Federal do Rio Grande - Mestrado em Educação Ambiental.

1. Trabalho dos separadores resíduos. 2. Meio ambiente. 3. Saúde. I.Vaz, Marta Regina César. II.Título. 


\section{PABLO VIANA STOLZ}

\section{A COMPREENSÃO DOS SEPARADORES DE RESÍDUOS SÓLIDOS EM RELAÇÃO AO SEU TRABALHO, SAÚDE E AMBIENTE}

Dissertação aprovada como requisito parcial para a obtenção do grau de Mestre em Educação Ambiental no Programa de Pós-Graduação em Educação Ambiental da Fundação Universidade Federal do Rio Grande - FURG. Comissão de avaliação formada pelos professores:
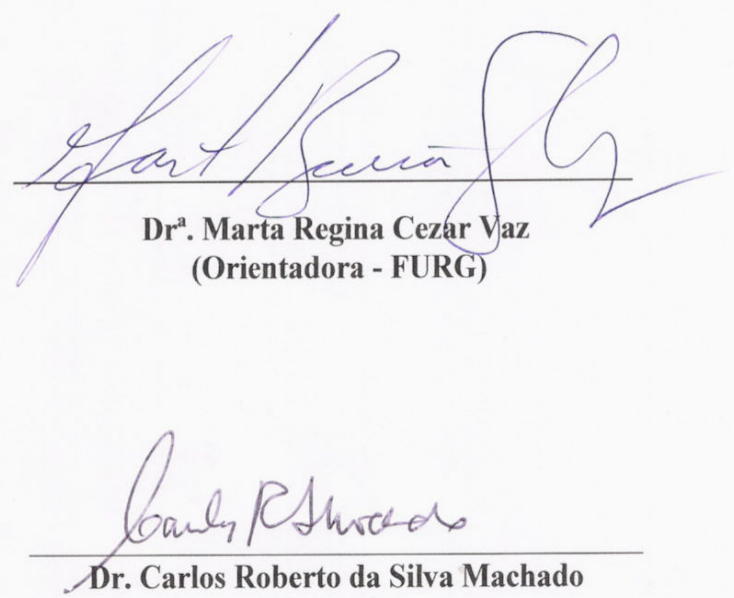

(FURG)

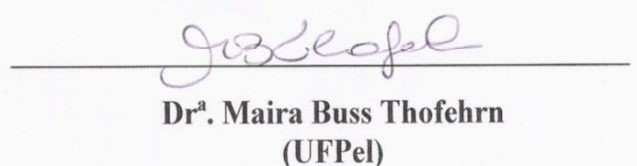

(UFPel) 


\section{AGRADECIMENTOS}

Por meio deste trabalho agradeço a todos que me apoiaram e incentivaram ao longo desses anos de estudo.

A Deus, por estar ao meu lado sempre, iluminando o caminho da minha vida e principalmente os momentos que me exigiram intensa dedicação.

A minha esposa Lucinéia, da qual eu me orgulho muito, pois é uma pessoa extraordinária, e sempre me apoiou em todos os momentos desta pesquisa. Te amo.

A minha filha Maria Eduarda, meu "tesourinho" que mesmo recém chegada ao mundo me trouxe mais motivação para a conclusão desta etapa da minha vida, e que é nossa anjinha, papai te ama muito.

A minha orientadora Professora Marta Regina Cezar Vaz, que acreditou em mim, me apoiou e depositou um oceano de conhecimento, muito obrigado.

Aos trabalhadores separadores de resíduos da ASTARR, que concordaram em participar desta pesquisa, disponibilizando um pouco de seu tempo para que eu conhecesse um pouco desta profissão tão árdua, mas com uma importante contribuição social.

A todos que transformaram meu ideal em realização, um muitíssimo obrigado. 


\section{RESUMO}

O trabalho apresenta resultados de uma pesquisa que teve como objetivo compreender as relações que os trabalhadores separadores de resíduos desenvolvem entre o seu trabalho e o ambiente; entre o seu trabalho e a saúde e de identificar de que maneira estes compreendem o seu trabalho como um processo pedagógico ambiental. Esta pesquisa foi desenvolvida com separadores pertencentes à associação dos trabalhadores de resíduos sólidos (ASTARR), do município de Rio Grande - RS. Realizou-se entrevistas com oito separadores, que foram tratadas pela análise de conteúdo. Os dados revelaram algumas significações positivas, como a preservação ambiental, através da limpeza e do não desmatamento, a questão da renda como sustento familiar e a iniciativa para conscientização ambiental por meio de aulas de reforço para escolares. Como significações negativas surgiram o não reconhecimento destes profissionais pela comunidade, poucos diálogos com os moradores locais e a não utilização de equipamentos de proteção no desenvolver de suas atividades.

\section{Palavras-Chave:}

Trabalho dos separadores resíduos - meio ambiente - saúde 


\section{RESUMEN}

El documento presenta los resultados de una encuesta que tuvo como objetivo entender las relaciones que los trabajadores de residuos separadores desarrollan entre su trabajo y el medio ambiente; su trabajo y la salud e identificar de que manera entienden su trabajo como un proceso entorno educativo. Esta investigación fue desarrollada con separadores de residuos pertenecientes a la asociación de trabajadores de residuos sólidos (ASTARR), del municipio del Rio Grande - RS. Hubo entrevistas con ocho separadores, que fueron abordadas por el análisis del contenido. Los datos revelaron algunos significados positivos, tales como la preservación del medio ambiente, por medio de la limpieza y no deforestación, la cuestión de la renta como medio de subsistencia familiar y la iniciativa de la conciencia ambiental a través de clases de auxilio para estudiantes. En los significados negativos surgieran el no reconocimiento de estos profesionales por la comunidad, son pocos los diálogos con los residentes locales y la no utilización de equipos de protección para desarrollar sus actividades.

Palabras Clave:

Trabajo de los separadores de residuos - medio ambiente - la salud 
SUMÁRIO

1 INTRODUÇÃO

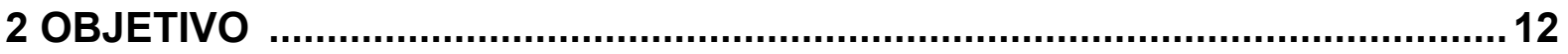

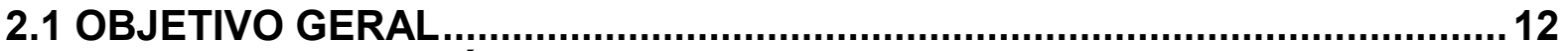

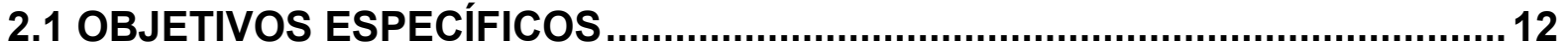

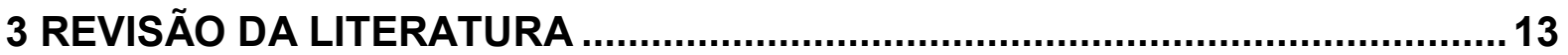

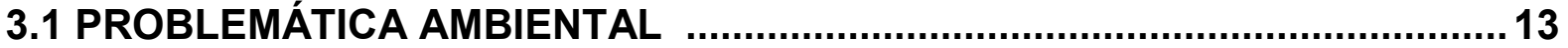

3.2 CONCEITO DE LIXO E RESÍDUOS .......................................................... 17

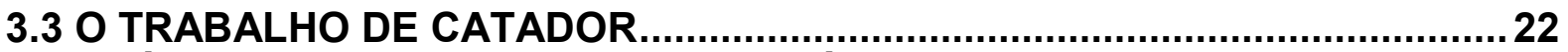

3.4 SAÚDE E O TRABALHO COM OS RESÍDUOS …........................................26

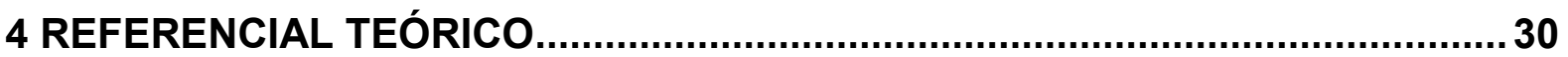

4.1 RACIONALIDADE AMBIENTAL …...................................................... 30

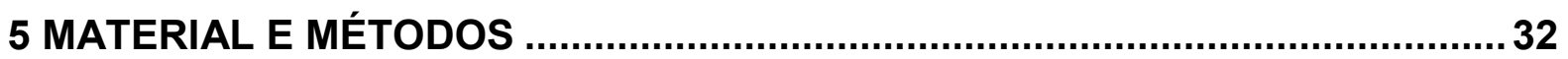

5.1 TIPO DE ESTUDO

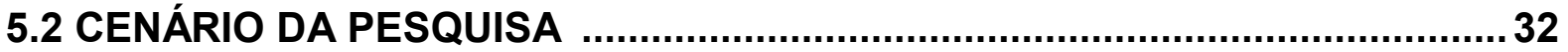

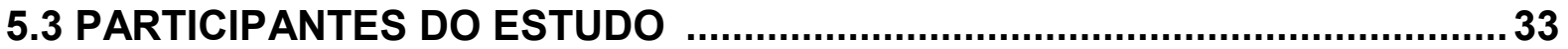

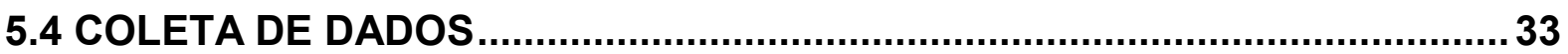

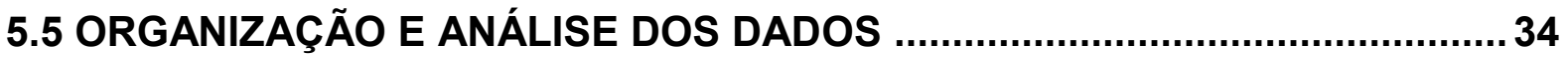

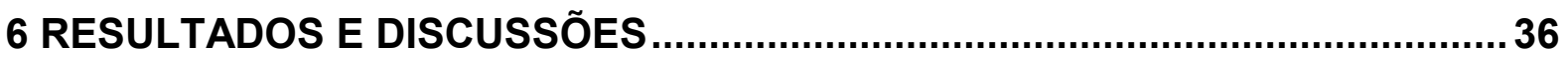

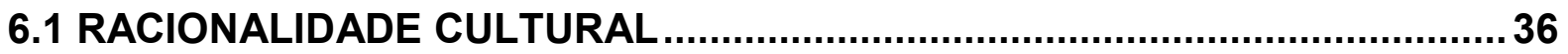

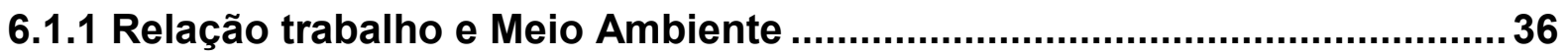

6.1.2 Relação Trabalho e comunidade ........................................................43

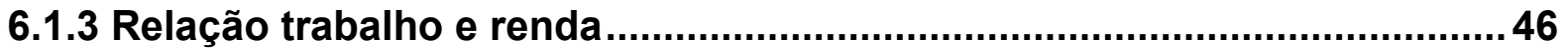

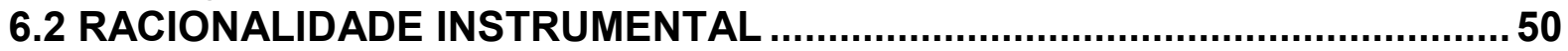

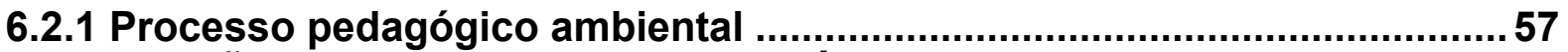

6.3 RELAÇÕES ENTRE TRABALHO E SAÚDE .........................................60

6.3.1 0 uso de Equipamentos de Proteção ..................................................60

6.3.2 Riscos e Perigos no desenvolver de seu Trabalho .................................63

6.3.3 Trabalho e ferimentos ............................................................................68

6.3.4 Mudanças para melhorar a saúde no trabalho …….................................70

6.3.5 Mudanças para melhorar a saúde na comunidade..................................... 73 


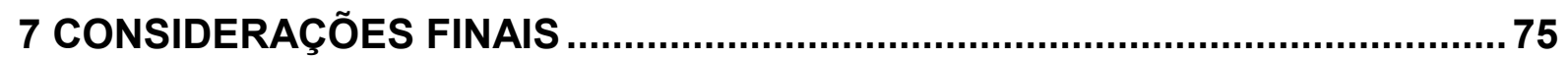

8 REFERÊNCIAS

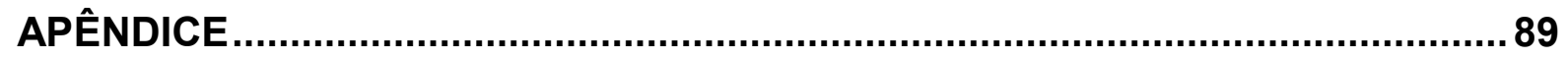

ANEXO 


\section{INTRODUÇÃO}

Qualquer ser vivo gera, através de sua atividade metabólica, algum tipo de rejeito. Ou seja, absorve matéria, transforma-a em energia, incorpora uma parte como biomassa e excreta o excedente ou o que não lhe é útil. Esse fenômeno, que ocorre a todo o momento no Planeta, é condição indispensável à vida. Nós, seres humanos, geramos, ainda, outros tipos de resíduos, os resíduos sólidos que são resultantes da atividade doméstica e comercial e pode ser constituído de matéria orgânica, papel, plástico, vidro ou metais.

Atualmente, a população mundial vem enfrentando sérias dificuldades para resolver as questões relacionadas aos resíduos, os quais vêm sendo encarados como um problema de saúde pública (CASTIEL, 2001). Na sociedade contemporânea, com a maioria das pessoas vivendo nas cidades e com o avanço mundial da indústria, provocando mudanças nos hábitos de consumo da população, têm-se gerado resíduos em excesso, fato este que, associado ao desemprego e o empobrecimento, tem levado muitos brasileiros a procurar o seu sustento através da catação de resíduos.

A problemática do lixo, historicamente, vem se agravando na medida em que a sociedade, com o objetivo de atender suas necessidades ${ }^{1}$, aumenta o consumo. $O$ lixo é, portanto, um dos subprodutos do conjunto de atividades desenvolvidas pela sociedade.

Nesta perspectiva encontra-se nos locais de recepção dos resíduos o catador $^{2}$, desenvolvendo a função de separador de lixo, à espera da matéria prima que possibilite a sua sobrevivência. Hoje, o lixo, cada vez mais opulento, oferece campo para uma estratégia de sobrevivência ligada à coleta do reciclável do descarte urbano. Na perspectiva do pobre urbano, o lixo é fonte renovável de recursos naturais, na qual ele "garimpa" e cria mercadorias (LESSA, 2000, p. 15).

$\mathrm{O}$ catador, na condição de sobrevivente dos restos da sociedade - os quais representam para ele a sua mercadoria - fica exposto a um sentimento de baixa auto-estima. A ocupação ainda é considerada como algo desprezível pela população

\footnotetext{
${ }_{1}^{1}$ Aquilo que é realmente indispensável, segundo dicionário de português.

${ }^{2}$ São trabalhadores que desenvolvem a atividade de separação de resíduos recicláveis.
} 
e pelo próprio catador. Muitas vezes, os catadores são tratados como portadores de doenças contagiosas, ladrões, dependentes químicos ou simplesmente vistos como alguém que não deveria estar presente no mundo - como o mendigo, o miserável, o louco ou o homicida, os quais a sociedade normalmente atribui à culpa por suas precárias condições de existência (VELLOSO, 2008).

Segundo o Fundo das Nações Unidas Para a Infância (UNICEF, 2002), não há estatísticas precisas sobre o número de catadores de lixo, porém a campanha Criança no Lixo Nunca Mais enviou questionários a todas as prefeituras do Brasil, com o intuito de levantar dados sobre a realidade das crianças e adultos que vivem dos resíduos. Estima-se que haja mais de 500 mil catadores adultos no Brasil que trabalham nos resíduos. Outros dados indicam que em $68 \%$ dos municípios brasileiros há catadores nas ruas e $66 \%$ nos aterros.

Diante disto, acredita-se que através da educação ambiental, inserida na saúde pública, possam-se buscar soluções mais adequadas para melhorar as condições de trabalho dos separadores de resíduos recicláveis. No entanto, este entendimento só foi possível depois de decorrida certa trajetória de vida, que se iniciou em 1999, quando iniciei a faculdade de Enfermagem e veio a culminar no decorrer do curso de mestrado em Educação Ambiental pela Universidade Federal de Rio Grande.

Foi através deste contato com a área da enfermagem e com a educação ambiental, que percebi existir a atuação de uma política pública, com caráter ambiental, voltada para a saúde da comunidade, podendo prevenir, de forma eficiente, muitos agravos a estas pessoas.

Desta maneira, consegui obter subsídios necessários para poder realizar esta pesquisa, cujo tema me inquietava já há algum tempo, como as questões relacionadas aos resíduos sólidos recicláveis, principalmente quando neste encontram-se pessoas separando-os, as quais são, por nós, deixadas e consideradas como algo sem valor, não dando, muitas vezes, importância ao seu destino, preferindo ignorá-las do nosso cotidiano, e desta forma ignorando, também, aquelas pessoas que sobrevivem destas sobras.

Preocupando-me com a condição precária, a que estão submetidas estas pessoas ao desempenharem seu trabalho, principalmente no que se refere a sua saúde, pois estão propícias a adquirir doenças vinculadas a sua atividade, é que 
venho apresentar esta dissertação de mestrado. Em virtude disso pesquisou-se o universo dos separadores de resíduos recicláveis, os quais exercem seu trabalho em uma associação localizada no bairro Castelo Branco II, do município do Rio Grande.

Justifica-se a realização do presente estudo uma vez que o cotidiano dos sujeitos que vivem da reciclagem do lixo ainda é pouco trabalhado pela saúde pública brasileira (PORTO et. al., 2004). Acredita-se, ainda, que esta pesquisa possa servir de subsídio para profissionais da área da saúde e para educadores ambientais que estejam inseridos na comunidade ou tenham interesse no assunto, já que a questão dos resíduos implica diretamente na saúde da população. Foi em virtude desses fatos que surgiu a necessidade em aprofundar este tema, entrevistando os separadores de resíduos, para saber o que pensam em relação ao seu trabalho e as implicações em sua saúde, surgindo, assim, a seguinte questão de pesquisa:

"Como os trabalhadores separadores de resíduos compreendem o seu trabalho, com relação ao ambiente e saúde". 


\section{OBJETIVO}

\subsection{OBJETIVO GERAL}

Identificar, no coletivo dos trabalhadores, a caracterização da racionalidade instrumental e cultural no seu trabalho.

\subsection{OBJETIVOS ESPECÍFICOS}

Compreender as relações que os trabalhadores, separadores de resíduos, desenvolvem entre o seu trabalho e o ambiente.

Compreender as relações que os trabalhadores, separadores de resíduos, desenvolvem entre o seu trabalho e a saúde.

Identificar a maneira como os trabalhadores compreendem o seu trabalho como um processo pedagógico ambiental. 


\section{REVISÃO DA LITERATURA}

Neste capítulo, apresenta-se a revisão literária, a qual se considerou relevante para esta pesquisa, pois aborda sobre a problemática ambiental, o aspecto da globalização e desta com a questão dos resíduos. No segundo tópico, mencionam-se algumas definições sobre lixo e resíduos. Já no terceiro tópico, o tema em especifico é sobre o trabalho dos catadores de resíduos, e no quarto tópico apresentam-se questões que envolvem a saúde destes separadores com relação ao seu trabalho.

\subsection{PROBLEMÁTICA AMBIENTAL}

A exploração dos recursos naturais, associada a uma sociedade construída sobre as bases insustentáveis do consumo, do industrialismo, do materialismo, da competição, da dominação dos seres humanos por outros seres humanos, colocou a humanidade frente a um dilema: buscar um progresso material à custa da degradação ambiental, que, cada vez mais, agrava a problemática socioambiental (CARVALHO, 2004).

A partir da Segunda Guerra Mundial, desenvolveu-se, no mundo, um amplo processo de globalização ${ }^{3}$ das relações, processos, estruturas de dominação e apropriação, antagonismo e integração. Todas as esferas da vida social, coletiva e individual, de certa forma, são alcançadas pelos problemas e dilemas de tal era (FERREIRA, 2004).

Com o avanço dos processos de industrialização, urbanização e crescimento demográfico houve um aumento crescente da produção de resíduos, que passou a ter uma composição cada vez mais diversificada e perigosa.

O excessivo uso de recursos naturais como matéria prima para a produção

\footnotetext{
${ }^{3}$ Conforme Gonçalves (1999), a globalização é um dos processos de aprofundamento da integração econômica, social, cultural, política e espacial e barateamento dos meios de transporte e comunicação dos países do mundo. É um fenômeno capitalista e complexo que começou na época dos descobrimentos e que se desenvolveu a partir da Revolução Industrial.
} 
industrial, acompanhado por hábitos de consumo e desperdício altamente estimulados na população, contribuíram para a geração ampliada e variada de resíduos. Neste contexto, cada vez mais produtos são produzidos, redundando em mais e mais resíduos. Isso é agravado com a utilização crescente de embalagens descartáveis de alumínio, de ferro, de vidro, de plástico e de papel (GONÇALVES, 2004b).

Segundo Eigenheer (2003), a partir da lógica capitalista, cria-se um paradoxo, do qual é preciso consumir cada vez mais para viver e manter-se na vida moderna, ao mesmo tempo, que se torna necessário evitar que o produto final desse consumo - o lixo - nos ameace.

Para Rodrigues (2000), trata-se de um problema de civilização ${ }^{4}$, para o qual não há saída, pois o lixo não é senão a outra face da moeda de um modo de produção. Desse modo, uma sociedade de produção em massa, industrial e de consumo é, necessariamente, uma sociedade de produção em massa de lixo.

Paralelo a tudo isso, o processo de globalização atual, imposto pelos países desenvolvidos e o surgimento de novas tecnologias, impulsiona uma reestruturação na economia mundial, através do avanço das empresas privadas. A implantação de novas tecnologias nos modos de produção proporciona, assim, uma exclusão da grande parcela de trabalhadores no mercado formal (GONÇALVES, 1999) ${ }^{5}$.

O Brasil, como país com um modelo de desenvolvimento voltado para a maximização do lucro, onde beneficia o capitalista, sofre as conseqüências da mundialização do capital $^{6}$. Estas são refletidas diretamente nos índices de desemprego e subemprego do país. Este quadro proporciona um crescimento econômico de caráter excludente, com a alta elevação do setor informal da sociedade. Tais efeitos são vivenciados, principalmente, nas classes menos favorecidas, as quais não têm acesso à informação básica (GONÇALVES, 2004a).

A constatada crise da economia mundial apresenta conseqüências desastrosas para a maioria dos países. Conforme Adrioli (2002), a economia

\footnotetext{
${ }^{4}$ No sentido de cultura

${ }^{5}$ Sugere a leitura do livro Globalização e Desnacionalização de Reinaldo Gonçalves

${ }^{6}$ A nova etapa de desenvolvimento do capitalismo mundial, que surge a partir da década de 1980 constituída pelo poder crescente do capital-dinheiro altamente concentrado, ocorrida, principalmente entre o período de 1985 e 1995. Sugere a leitura do livro "Trabalho e Mundialização do capital - A Nova Degradação do Trabalho na Era da Globalização", de Giovanni Alves, Editora Praxis, 1999)
} 
mundial que se mantinha num crescimento de $4 \%$ na década de 60 , chegou ao final da década de 90 com apenas 1\%. O custo social disso, por sua vez, é catastrófico: a diferença entre países ricos e pobres aumentou em 110 vezes, desde a $2^{\mathrm{a}}$ Guerra Mundial até a década de 90, aumentando consideravelmente a distância entre ricos e pobres dentro dos países.

De acordo ainda com Adrioli (2002), de maneira mais conjuntural, as principais características decorrentes da crise mundial são as seguintes: a) crise do trabalho assalariado, com acentuada precarização nas relações de trabalho; b) despolitização das relações sociais; c) acento na competitividade com a perspectiva de que apenas alguns se "salvam" já que não há "espaço" para todos; d) reestruturação produtiva; e) tentativa de substituição do modelo fordista / taylorista de produção, alterando as formas de gestão tradicionais nas empresas; f) incorporação de novas tecnologias, dispensando atividades repetitivas e gerando problemas de qualificação profissional; g) corte de gastos públicos e a conseqüente redução das políticas sociais.

O desemprego, que daí decorre, atinge praticamente a todos os países, numa dimensão nunca antes vista. Conforme estudo intitulado "Tendências Mundiais de Emprego -2004", realizado pela Organização Internacional do Trabalho - OIT - o total de desempregados no mundo no final de 2003 foi de 185,9 milhões de pessoas, o que corresponde a $6,2 \%$ da força de trabalho do planeta. É o maior número da história da OIT, superando a marca de 185,4 milhões de desempregados atingida em 2002. No Brasil, segundo o $\mathrm{IBGE}^{7}$, o número de desempregados nas seis maiores regiões metropolitanas do país, onde o índice é medido, manteve-se, em julho de 2008, em 2,2 milhões, e na região de Porto Alegre o número de desempregados correspondeu a 245 mil indivíduos.

Em um mundo de desemprego crescente, em que a grande maioria dos trabalhadores não controla nem participa da gestão dos meios e recursos para produzir riquezas, um número sempre maior de trabalhadores e famílias perde acesso à remuneração e fica excluído do mercado capitalista.

A introdução de novas tecnologias nos processos produtivos em muitos países, com objetivo de elevar os níveis de produção e a redução de custos, é um elogio ao saber técnico e racional, peculiar à sociedade capitalista. Elas são apropriadas pelos

\footnotetext{
${ }^{7}$ Instituo Brasileiro de Geografia e Estatística.
} 
detentores do meio de produção (o capitalista), que as utilizam com o intuito de melhorar a qualidade de seus produtos e reduzir seus custos para competir no mercado (RÊGO et al, 2002), muitas vezes, explorando o próprio trabalhador e a natureza.

Exigem, com isso, uma qualificação e escolaridade máxima. $E$, àqueles, que não têm acesso a essa especialização, resta à marginalização ou exclusão ${ }^{8}$ do sistema, resultado do progresso econômico, não acessibilidade aos bens de consumo e serviços. Soma-se, a tal processo, a insuficiência de oportunidades que possibilite um movimento contrário a este cenário (RÊGO et al, 2002).

Provocada pelo próprio sistema capitalista, a exclusão social em que se encontram muitos seres humanos, tem levado à formação, no mundo todo, de um exército de pessoas que trabalham e vivem com recursos provenientes de resíduo urbano (MAGERA, 2003).

Os pobres urbanos, desempregados, "biscateiros", ambulantes, catadores de lixo, moradores das ruas, dos albergues, de cortiços e favelas, analfabetos, semianalfabetos ou simplesmente despreparados para os complexos serviços urbanos, são os que mais visivelmente são atingidos pela forma excludente e segregacionista, como crescentemente se têm organizado as cidades (GONCALVES, 2004).

Todas essas problemáticas são resultados da atual política mundial, que visando buscar a inclusão da sociedade na globalização acaba por excluir uma grande parcela da população que não tem acesso algum a educação, saúde, cultura, informação, ficando desta maneira marginalizada socialmente.

A pobreza, em princípio originada por medidas econômica recessiva, desemprego, desaceleração das atividades produtivas, demonstra claramente que os ajustes estruturais e a globalização da economia não estão sendo capazes de propiciar melhoria nas condições de vida para uma grande parcela da população. Uma das conseqüências mais graves dessa situação de miséria é a presença de centenas de famílias morando ao lado dos lixões nas cidades, buscando opções de sustento através de diversas estratégias de sobrevivência (FERREIRA e ANJOS, 2001).

\footnotetext{
${ }^{8} \mathrm{O}$ conceito de exclusão social é, em sua essência, multidimensional, incluindo uma idéia de falta de acesso não só a bens e serviços, mas também à segurança, à justiça e à cidadania. Para Sposati (1999), "exclusão é um processo complexo, multifacetado, que ultrapassa o econômico do ponto de vista da renda e supõe a discriminação, o preconceito, a intolerância e a apartação social" (p.103).
} 
"Coletar lixo" acaba sendo uma alternativa encontrada por alguns desses excluídos, pois como não atingem a qualificação exigida pelo mercado, vêem nessa função uma estratégia de sobrevivência. Ainda sendo uma forma de trabalho vista como degradante pela sociedade, os "catadores de materiais recicláveis" fazem do lixo uma forma de obter a renda para o próprio sustento (FERREIRA e ANJOS, 2001).

Este quadro se reflete, principalmente, no incremento da coleta informal, atividade que, contribui, significativamente, para a degradação da qualidade de vida da população, devido às condições às quais estes trabalhadores são expostos.

\subsection{CONCEITO DE LIXO E RESÍDUOS}

Pode-se verificar na história, que os restos estão sempre associados ao corpo do ser humano e às suas atividades. Na Antiguidade, o homem guardava os restos mortais dos seus antepassados nas cavernas, onde ele sempre voltava para render culto aos que vieram antes e apaziguar os espíritos. Aos poucos, esse espaço foi se tornando local de habitação, de moradia, e o homem foi deixando de ser um nômade, acostumando-se a um lugar. É interessante notar que a origem das palavras morada, morte e costume, é a mesma - mor, moris (VELLOSO, 2004).

$\mathrm{Na}$ Idade Média, a maioria dos restos resultantes da atividade do homem estava diretamente relacionada aos resíduos produzidos pelo seu corpo - fezes, urina, secreções em geral e o próprio corpo humano em decomposição. Também havia os restos provenientes da alimentação: carcaças de animais, cascas de frutas e hortaliças (VELLOSO, 2004).

Os restos começaram a causar medo no homem, a partir do momento em que foram sendo associados ao seu sofrimento físico e psíquico. Esse sofrimento ficou bem marcado na ocasião do surto manifestado pelas epidemias e pandemias de algumas doenças (VELLOSO, 2008).

A partir do século $X X$, a concentração populacional e o processo de industrialização trouxeram um aumento da quantidade de lixo e também mudanças na sua composição. Ao lixo, que até então era formado por restos de alimentos, cascas e sobras de vegetais e papéis, foram sendo incorporados novos materiais 
como vidro, plásticos, isopor, borracha, alumínios entre outros de difícil decomposição. Para se ter uma idéia, enquanto que os restos de comida deterioram-se rapidamente, o papel demora entre 3 a 6 meses para se decompor, o plástico dura mais de cem anos, já o vidro cerca de 1 milhão de anos, quando jogados na natureza (VELLOSO, 2004).

Segundo Sisinno (2000) a denominação "lixo", como a maioria das palavras da língua portuguesa, vem do latim LIX, que quer dizer cinza. Este termo vem de uma época bastante remota, quando eram usados fornos, fogões e lareiras à base de lenha que formavam resíduos da lenha carbonizada e cinza. Os referidos autores, afirmam que, de um modo geral, todos os resíduos eram aproveitados para a alimentação de animais como porcos e galinhas, ou como adubo para a plantação. Hoje, o lixo não contém somente cinzas, e a palavra "lixo" passou a denominar, genericamente, tudo aquilo que não tem mais serventia e se joga fora.

O lixo é normalmente definido como todo o resíduo sólido resultante das atividades humanas. Estes resíduos podem ser objetos que não mais possuem valor econômico ou utilidade, como também porções de materiais sem qualquer significação, resíduos de processos industriais ou domésticos a serem descartados, enfim, qualquer coisa sem utilidade e que se jogue fora. Em relação a esta definição apresentada, deve-se levar em consideração que o conceito de utilidade é relativo, visto que o que é descartado por alguns, considerado como lixo, pode ser aproveitado originalmente por outros; da mesma maneira que objetos ou materiais que em pequena quantidade não são relevantes, podem ter importância econômica se em quantidade suficiente (RANCURA, 2005).

Quando se fala de lixo a imagem que se forma, para a maioria das pessoas, é a daquilo que sobra e não tem mais valor, tendo uma acepção sempre negativa. No dicionário Houaiss (2001), a palavra lixo está designada como:

\footnotetext{
Qualquer objeto sem valor ou utilidade, detrito oriundo de trabalhos domésticos ou industriais que se joga fora; uso informal ou de forma pejorativa: coisa ordinária, malfeita, feia; pessoas sem qualquer dote moral, físico ou intelectual; a camada mais baixa da sociedade; escória, ralé.
}

Portanto, usar a noção de lixo é uma forma provocativa e adequada para discutir resíduos em seu contexto social e de exclusão na atual sociedade capitalista. A qual exclui o trabalho vivo e invisível dos catadores (RANCURA, 2005). 
Já o resíduo é caracterizado como um termo técnico ou neutro, com uso em meios acadêmicos ou profissionais. O dicionário Houaiss (2001) apresenta o termo resíduo como "aquilo que sobra, o que resta de qualquer processo".

Conforme Rancura (2005), os resíduos podem ser classificados por sua natureza física (seco e úmido), por sua composição química (orgânico e inorgânico) ou, segundo a ABNT (NBR 10004, de SET/1987), pelos riscos potenciais que representam para o meio ambiente e saúde pública (perigoso não inerte e inerte). Outra classificação possível para os resíduos está relacionada aos locais onde são gerados, sendo que, de acordo com sua origem e natureza, recebem diferentes destinações (IPT/SEBRAE, 2003; MAGERA, 2003; ROTH et al, 1999). Desta forma, temos: resíduo domiciliar: são os resíduos gerados diariamente nas residências; Resíduo comercial: originados nos estabelecimentos comerciais e de serviços, como bancos, lojas e supermercados; resíduo público: resíduos originados dos serviços de limpeza pública; resíduo industrial: resultantes dos processos industriais e rejeitos das indústrias ou refugos da produção; resíduo agropecuário: produtos químicos resultantes das atividades agropecuárias com potencial para contaminação do ambiente, como embalagens de fertilizantes, agrotóxicos e remédios veterinários; resíduo da construção civil: constituído por materiais de demolição ou restos de materiais de construção; resíduo de serviços de saúde e hospitalar: produzido por laboratórios, clínicas, hospitais, farmácias e ambulatórios, entre outros. São resíduos com alto potencial para contaminação de pessoas e ambiente. Devem ser incinerados; resíduo de portos, aeroportos e terminais de transporte: resíduos provenientes destes locais recebem atenção especial como medida de controle e prevenção de introdução de agentes causadores de doenças e epidemias.

Ficam incluídos nesta definição os lodos provenientes de sistemas de tratamento de água, gerados em equipamentos e instalações de controle de poluição, bem como determinados líquidos cujas particularidades tornem inviável o seu lançamento na rede pública de esgotos ou corpos d'água, ou exijam, para isto, soluções viáveis técnica e economicamente face à melhor tecnologia disponível.

$\mathrm{Na}$ mesma norma, a periculosidade de um resíduo é definida a partir das características que apresenta e que, em função de suas propriedades físicas, químicas ou infecto-contagiosas, pode constituir: (I) risco à saúde pública, provocando ou acentuando, de forma significativa, um aumento de mortalidade ou 
incidência de doenças e/ou; (II) riscos ao ambiente, quando o resíduo é manuseado ou destinado de forma inadequada.

Outra forma de caracterização está relacionada ao uso que se faz do resíduo após este ter cumprido a função à qual foi primariamente destinado. Baseado nas definições de Mancini (1999) e Logarezzi (2004) existe: resíduo reutilizável: é o resíduo que pode ser reaproveitado de forma inteira, sem a destruição do objeto em que consiste geralmente adaptado a uma nova função; resíduo reciclável: resíduo que pode servir como matéria prima para a confecção de novos produtos, através dos processos de reciclagem (resíduo reciclável seco) e compostagem (resíduo reciclável úmido); resíduo inservível: é aquele que num determinado contexto (local e época) não pode ser reutilizado e nem reciclado (LOGAREZZI, 2004).

Para Logarezzi (2004), tanto o lixo como o resíduo são sobras de uma atividade qualquer e o que as caracteriza como lixo ou resíduo depende dos "valores sociais, econômicos e ambientais" que atribuímos a elas, consubstanciados no ato do descarte. Dessa forma, segundo o autor, ao descartarem-se resíduos sem preservar seus valores potenciais, estes se transformam em "lixo", adquirindo "aspectos de inutilidade, sujidade, imundície, estorvo, risco ele...".

Rodrigues (2000) considera o lixo, e o resíduo, como um componente da sociedade industrial tão fundamental quanto à fábrica e o lucro, pois é em oposição a ele que se atribui sentido à lógica funcional e utilitarista sobre a qual o sistema de produção se estrutura. As mercadorias são vistas como antagônicas ao lixo, justificando um modelo de produção em massa, industrial e de consumo. Dessa forma, pensa-se o lixo como um problema da civilização; como é considerado o outro lado da produção, justifica-se o aumento na geração de lixo pela necessidade de produzir cada vez mais.

Com base nesta lógica, os seres humanos apropriam-se da natureza através do progresso tecnológico e induz a uma homogeneização dos padrões de produção e consumo, contrária à sustentabilidade do planeta, que tem por base a diversidade biológica e cultural (LEFF, 2003).

A industrialização, o crescimento demográfico, a concentração urbana e as tecnologias desenvolvidas são alguns dos principais fatores que tornam a questão dos resíduos algo bastante preocupante. A contínua criação de materiais artificiais 
(muitas vezes contaminantes) e o crescente consumo de bens e geração de resíduos, impulsionados pelo sistema de produção, colaboram para o esgotamento da capacidade ambiental de absorção dos impactos relacionados ao descarte de resíduos. Simultaneamente, a percepção do resíduo como um problema externo - a partir do momento em que é retirado de casa, acreditando estar livre dele - contribui para sua deposição irresponsável no ambiente. Dá-se pouca importância ao fato de que o material usado para a produção de itens que trazem o progresso e o conforto é tomado da natureza e a ela é retomado, assim que julgado inútil e classificado como lixo (RANCURA, 2005).

Estima-se que a geração de resíduos sólidos em todo mundo cresça $20 \%$ a cada ano (ROTH et al, 1999). No Brasil, a Pesquisa Nacional de Saneamento Básico 2000, realizada pelo IBGE, indica que a produção média de resíduos em cidades com até 200 mil habitantes é de 0,7 Kg por habitante/dia e para cidades com mais de 200 mil habitantes a produção aumenta para a faixa entre 0,8 e 1,2 Kg por habitante/dia (IBGE, 2002). A quantidade e a composição dos resíduos gerados refletem as diferenças do ambiente e dos aspectos sociais, econômicos e culturais de quem os descarta. De modo geral, regiões e comunidades mais ricas produzem uma maior quantidade de resíduos, com uma menor proporção de matéria orgânica. No Brasil, mais de 240 mil toneladas de resíduo são produzidas diariamente. Os principais destinos para essa quantidade de resíduo são os lixões, que recebem $30,5 \%$ do resíduo gerado no país, nos aterros controlados são depositados $22,3 \%$ do resíduo coletado e nos aterros sanitários, são enviados $47,1 \%$ de resíduo (IBGE, 2002). Os lixões implicam no lançamento do lixo sobre o terreno, sem qualquer cuidado ou técnica especial. Nos aterros controlados, o lixo é depositado e depois coberto com uma camada de terra, já o aterro sanitário apresenta técnicas especiais para o confinamento dos resíduos que evitam a contaminação do solo. Desta forma, uma enorme quantidade de resíduo, que poderia ser recuperado através da reciclagem e da compostagem, é perdida e passa a constituir fonte de contaminação para o ambiente. 


\subsection{O TRABALHO DE CATADOR}

Pode-se falar do trabalho humano desde os primórdios da humanidade. Contudo, Antunes (2004) esclarece que embora seja "ineliminável" da própria condição humana, o trabalho não é um objeto natural, mas uma ação essencial para estabelecer as relações entre o homem e a natureza, e entre as sociedades e a natureza.

O trabalho é elemento integrante da vida das pessoas, seja ou não na sua forma assalariada, pois se vive em uma sociedade em que é o trabalho que possibilita a construção de uma identidade, não só profissional como também pessoal, além de ser meio de reconhecimento e de valorização social. O trabalho tem um significado essencial no universo da sociabilidade humana, ele não é apenas meio de vida, ele forma a identidade da pessoa e a sua profissão caracteriza o seu modo de vida (MARINHO 2005).

Desde o início do processo de industrialização, surgiram pessoas que viviam do comércio de resíduos refugados. No começo do século $X X$, imigrantes já trabalhavam como compradores de sucata (metais ferrosos) e garrafas, e eram figuras respeitadas nos bairros e vilas (IPT/SEBRAE, 2003). Atualmente, o crescimento das cidades, a exclusão social e a mudança no modelo de consumo, aliado à aparição de um novo setor da economia - as indústrias de reciclagem -, proporcionou o surgimento de uma parte da população que trabalha e vive do resíduo urbano. A desestruturação das relações de trabalho associada à falta de oportunidades e à instabilidade as quais estão submetidos muitos trabalhadores, acabam por levar ao desenvolvimento de formas alternativas de trabalho, geralmente precárias e sem qualquer reconhecimento. A separação de resíduos recicláveis é uma destas atividades informais que, apesar de oferecer benefícios econômicos, sociais e ambientais, ainda é exercida sob péssimas condições, além de permanecer discriminada e sem reconhecimento (RANCURA, 2005).

Esta atividade de separação de resíduos recicláveis, realizada pelo catador, não se caracteriza como sendo um trabalho recente no cenário brasileiro. Segundo Juncá (2001), em 1857, um poema chamado 'O vinho dos trapeiros' de Charles Baudelaire, já fazia referência à atividade do catador. No Brasil, é a figura do 'velho 
garrafeiro', do começo do século XX, que põe em evidência tal atividade, que se expande com o desenvolvimento da sociedade industrial.

Já no final da Idade Média e na Modernidade, as pessoas que cuidavam do destino final do lixo eram marginais à sociedade. Assim, como o resto ou a sobra, esses seres humanos também eram escolhidos de acordo com a ocupação ou com o papel social que desempenhavam. Neste período, os serviços de limpeza estiveram freqüentemente subordinados ao carrasco da cidade, e eram executados pelos seus auxiliares. As tarefas ligadas aos dejetos, inclusive o destino de cadáveres, eram delegadas a prostitutas, prisioneiros de guerra, condenados, escravos, ajudantes de carrascos e mendigos. Tal fato é importante para a compreensão de como o trabalho com resíduos foi sendo socialmente desqualificado. Segundo Hösel, a partir de 1624, na cidade de Berlim, Alemanha, começou-se a empregar prostitutas na limpeza das ruas, usando-se como argumentação o fato de que elas "usavam mais as ruas do que os outros cidadãos" (EIGENHEER, 2003).

Trata-se assim de uma atividade antiga, mas que vem se expandindo ao longo dos anos constituindo-se como possível mercado de trabalho, em relação direta com a grande quantidade e qualidade de resíduos sólidos produzidos no país. Selecionando e catando materiais recicláveis, homens e mulheres exercem uma atividade que constitui o primeiro elo do circuito econômico que gira em torno da reciclagem.

Dessa forma, conclui Leal (2002) que o catador de material reciclável participa como elemento base de um processo produtivo bastante lucrativo, no entanto, paradoxalmente, trabalha em condições precárias, subumanas e não obtém ganho que lhe assegure uma sobrevivência digna.

Magera (2003) relaciona o crescimento do número de catadores de materiais recicláveis com as crescentes exigências para o acesso ao mercado formal de trabalho e também ao aumento do desemprego. Para este autor, alguns trabalhadores da catação constituem uma massa de desempregados que, por sua idade, condição social e baixa escolaridade, não encontram lugar no mercado formal de trabalho.

No Brasil, estima-se que o número de catadores de materiais recicláveis seja de aproximadamente 500.000 (quinhentos mil), estando 2/3 deles no Estado de São 
Paulo. Embora a catação seja tal como a atividade de vendedor ambulante, realizada informalmente, a partir da década de 1980, os catadores começaram a se organizar em associações ${ }^{9}$ ou cooperativas ${ }^{10}$, na busca pelo reconhecimento dessa atividade como profissão. Nos anos 1990, com o apoio de instituições não governamentais, foram promovidos encontros e reuniões em vários locais do país com essa finalidade. Novos parceiros foram incorporados, e o ano de 2001 culminou com a realização do "1 Congresso Nacional de Catadores de Materiais Recicláveis e a $1^{\text {a }}$ Marcha da População de Rua" (MAGERA, 2003, p. 105). Com o fortalecimento dessas manifestações, criou-se o movimento nacional de catadores.

Entretanto, somente em 2002 a ocupação, catador de material reciclável, foi incluída na Classificação Brasileira de Ocupações - CBO. Nessa classificação, os catadores de lixo são registrados pelo número 5192-05 e sua ocupação é descrita como catador de material reciclável, cabendo a esse profissional: catar, selecionar e vender materiais recicláveis como papel, papelão e vidro, bem como materiais ferrosos e não ferrosos e outros materiais reaproveitáveis. Tais atividades podem ser desenvolvidas de formas e em locais diferenciados. Isto significa dizer que existem, por exemplo, trabalhadores autônomos e os que se acham subordinados, formal ou informalmente a uma estrutura de trabalho. Da mesma forma, existem os que estão nas ruas, em vazadouros, galpões, cooperativas ou associações (<http://www.ministeriodotrabalho. gov.br>).

No ano de 2003, o Governo Federal criou o comitê de inclusão social de catadores de lixo. Dentre outras atribuições, esse comitê deveria implantar projetos que visassem garantir condições dignas de vida e trabalho à população catadora de lixo, bem como apoiar a gestão e destinação adequada de resíduos sólidos nos municípios brasileiros.

Contudo, observa-se que os catadores desempenham suas atividades em condições precárias, sofrem preconceitos e possuem baixo reconhecimento do papel que representam na economia e no meio ambiente, embora tenham a profissão reconhecida e sejam resguardados por um comitê específico (MEDEIROS e MACEDO, 2007).

\footnotetext{
9 Associações são organizações que tem por finalidade a promoção de assistência social, educacional, cultural, representação política, defesa de interesses de classe, filantrópicas.

${ }^{10}$ Cooperativas têm finalidade essencialmente econômica. Seu principal objetivo é o de viabilizar o negócio produtivo de seus associados junto ao mercado.
} 
Para Miura (2004), o problema hoje não está em reconhecer legalmente o catador como um profissional, mas sim, em reconhecer seu direito às condições dignas de trabalho e de vida para além da perspectiva estrita da sobrevivência.

Segundo Migueles (2004), para que a sociedade perceba o catador como outro trabalhador qualquer, é preciso associar o trabalho de catação a significados positivos.

Esses autores correlacionam o caráter excludente do trabalho do catador à semântica negativa do lixo, e que essa situação interfere na imagem que o catador faz de si. Para Migueles (2004), o trabalho com o lixo interfere tanto na identificação do catador com o seu trabalho como no reconhecimento da sociedade pelo trabalho desempenhado pelo catador.

Estas pessoas desempenham seu trabalho tendo que conviver com a discriminação social. A imagem do "catador do lixo" é provocadora por expor de forma pública a pobreza. São os marginalizados, restritos às encostas, circulando nos bairros comerciais e espaços centrais da cidade. É esse o confronto travado, o desconforto causado por passantes. São estereótipos e modelos retificados que impedem a superação e o amadurecimento das relações cotidianas na cidade (FERREIRA, 2004).

Conforme Miura (2004) catar lixo é considerado uma atividade excludente pela própria natureza do tipo de trabalho. Entretanto, a mídia em geral, alguns estudiosos e instituições de diversos setores divulga que a catação constitui uma possibilidade de inclusão social de uma parcela de trabalhadores.

Já para Gonçalves (2004b), é um grande engano considerar que esses catadores são supérfluos do ponto de vista da acumulação global, porque vivem dos restos da sociedade. Eles se encontram integrados à economia, ainda que pela via mais perversa de um trabalho informal socialmente não reconhecido. Embora a reciclagem dos resíduos seja um negócio economicamente rentável, o ciclo de comercialização tem se conservado à margem da legalidade, fazendo com que o trabalho dos catadores seja o elo inicial de uma engrenagem econômica, que se reproduz em condições de marginalidade, na ausência quase absoluta de direitos trabalhistas e na compra de mercadorias por parte dos intermediários e das fábricas de modo informal. 
Portanto, os catadores de materiais recicláveis são partes fundamentais da cadeia produtiva dos materiais recicláveis, ainda que de forma marginalizada pelos sujeitos econômicos e governamentais. Isso nos leva a concluir que, contraditoriamente ao enquadramento na categoria de excluídos, que pressupõe a não utilidade, os catadores de materiais recicláveis são trabalhadores úteis, dos quais ainda é possível a extração de mais-valia ${ }^{11}$. Tais catadores vivem, na verdade, um processo de exclusão/inserção social, onde suas vidas são permeadas por zonas de vulnerabilidades, fragilidades e precariedades (GONÇALVES, 2004b).

\subsection{SAÚDE E O TRABALHO COM OS RESÍDUOS}

Qualquer que seja o conceito que se possa ter acerca do que seja saúde, não se pode deixar de reconhecer que ela está estreitamente relacionada com a maneira como ser humano produz seus meios de vida (trabalho) ou satisfaz suas necessidades (consumo), produzindo, nesse duplo movimento, as relações sociais que mantêm com outros homens. Essas duas dimensões essenciais e polares da existência humana não só condiciona, em ampla medida, o nível de saúde como também são por estas afetadas, visto que uma das conseqüências imediatas das enfermidades é a introdução de um desequilíbrio no ritmo 'normal' de trabalho e consumo (GONÇALVES, 2004b).

É fundamental enfrentar os determinantes da saúde (a alimentação, a moradia, o saneamento básico, o meio ambiente, o trabalho, a renda, a educação, o transporte, o lazer e o acesso aos bens e serviços essenciais ${ }^{12}$ ) em toda a sua amplitude, pois o modo de produção, as condições de trabalho e o modo de vida constituem o patamar para se analisar o processo de saúde, adoecimento e morte (GONÇALVES, 2004b).

É possível destacar certas características mais ou menos universais do processo de trabalho que influem invariavelmente sobre os níveis de saúde da população. Uma delas são a duração e a intensidade da jornada de trabalho. No que

\footnotetext{
${ }^{11}$ O custo de manutenção da força de trabalho (operário, maquinas) constitui seu valor; a mais-valia é a diferença entre o valor produzido pela força de trabalho e o custo de sua manutenção. A mais-valia é exatamente o valor que o operário cria além do valor de sua força de trabalho.

${ }^{12}$ Conforme Lei Federal no 8.088 de 19 de Setembro de 1990.
} 
se relaciona ao trabalho com resíduos recicláveis, a jornada de trabalho excessivamente longa e penosa tem efeitos adversos sobre a saúde, pelo desgaste físico que acarreta e pela permanente exposição a fatores nocivos do meio (sol, variações climáticas, vetores de agentes de doenças infecciosas, etc.) (VELLOSO, 2004).

Para Viana (2000), a vida de catador de lixo não é fácil. Além de enfrentar diariamente as intempéries da falta de organização comunitária, poucas pessoas separam o lixo seco do orgânico, os catadores têm que lidar o tempo todo com a sujeira e com os riscos ${ }^{13}$ de contrair doenças. A atividade é um reflexo da má distribuição de renda e de sociedades, onde impera a desigualdade social.

Atualmente, pode-se perceber que a constituição do lixo é diversificada e perigosa, em função do consumo desenfreado da sociedade capitalista e do aperfeiçoamento tecnológico. Conforme Samaja (2000), os resíduos sólidos urbanos (RSU), constituem uma preocupação ambiental mundial, especialmente em grandes centros urbanos de países subdesenvolvidos. Pouco se conhece sobre as repercussões da disposição desses resíduos a céu aberto na saúde humana e das práticas sanitárias da população em relação a eles. A geração de RSU, proporcional ao crescimento populacional, suscita uma maior demanda por serviços de coleta pública e esses resíduos, se não coletados e tratados adequadamente, provocam efeitos diretos e indiretos na saúde, além da degradação ambiental.

O impacto desse volume de lixo no meio ambiente das cidades é grande. A quantidade de dejetos só tende a aumentar e pode ocasionar escassez e esgotamento de recursos naturais, poluição do ar, da água, do solo, além de problemas de saúde pública, devido à proliferação de parasitas e surgimento de doenças.

Segundo Rouquayrol e Almeida (2003), o lixo representa um elemento que não deve ser desprezado no estudo da estrutura epidemiológica, uma vez que, pela sua variada composição, poderá conter agentes biológicos patogênicos ou resíduos

\footnotetext{
${ }^{13}$ Risco, de acordo com a Resolução CNS196/96, é a possibilidade de danos à dimensão física, psíquica, moral, intelectual, social, cultural ou espiritual do ser humano, em qualquer fase de uma pesquisa e dela decorrente. Caberia distinguir a noção de risco processo de risco produto. Risco processo é aqueles as que estão expostos os participantes de uma pesquisa, os próprios pesquisadores e os trabalhadores envolvidos, é aquele risco que ocorre ao longo do projeto. Risco produto é o risco decorrente do projeto, é aquele que atinge a sociedade de forma indistinta. É o risco que resulta dos rejeitos ou de outras formas de contaminação ambiental, por exemplo.
} 
químicos tóxicos que poderão alcançar o homem direta ou indiretamente, afetandoIhe a saúde.

No caso dos catadores de materiais recicláveis, que estão normalmente em contato contínuo e direto com o lixo, a exposição se dá através da inalação, do contato dérmico, contaminação via oral (principalmente de alimentos), causando determinadas patologias infecto-contagiosas, mormente nos aparelhos digestivo e respiratório - como tuberculose e pneumonia, além de existirem outros riscos como acidentes diversos (cortes, atropelamentos por caminhões e tratores) desenvolvendo o tétano, em função de estarem próximos a áreas violentas. Entretanto, inúmeras são as controvérsias quanto à periculosidade do lixo e suas conseqüências para o estado de saúde dos catadores de materiais recicláveis (GONÇALVES, 2004a).

Forantini (2000) relata que não é aplicada ao lixo a sua devida importância em termos de ameaça à saúde, sendo considerado como questão de estética, economia e conforto, do que como eminente causa direta de qualquer agravo à saúde. A respeito dos aspectos epidemiológicos ligados ao lixo, ele afirma que os resíduos sólidos, que são resultantes das atividades dos homens e animais domésticos, podem ser designados, genericamente, sob o nome de lixo. Uma vez preenchido a sua finalidade, é destinado a ser eliminado, surgindo então, a questão de sua destinação final. A solução desta problemática torna-se necessária, pois a permanência desses resíduos no meio-ambiente poderá redundar em efeitos negativos; tais como contaminação por agentes patogênicos, como também acidentes devidos a objetos perfurocortantes.

Oliveira (1969) aborda questões relativas aos aspectos relacionados ao lixo, quando relata que este pode manifestar-se de diferentes maneiras na transmissão de doenças, como, por exemplo, a triquinose, doença transmitida através da carne do porco, que foi alimentado com restos de alimentos ou com lixo em geral, que caso não tenha tido acondicionamento adequado, pode ter estado exposto a vetores como moscas, mosquitos e ratos, podendo, assim, transmitir entre outras doenças, a tuberculose, a febre tifóide, a peste bubônica, a tifo murino, a cólera, a amebíase, a giardíase, a ascaridíase, a malária, a febre amarela, a dengue e a leishmaniose.

Para Eigenheer (2003), o argumento do cuidado com a saúde dos catadores deve ser relativizado, já que a sustentação técnica se silencia diante de tantas outras atividades profissionais lesivas à saúde do trabalhador. A putrefação da 
matéria orgânica no entorno, a sujeira das roupas e o mau aspecto das pessoas que ali trabalham parecem ser insuportáveis para toda a sociedade.

Já Sisinno (2000), relatam que trabalhadores de usinas de reciclagem podem respirar material particulado, contendo microorganismos e endotoxinas se não usarem equipamentos adequados - e sofrerem ferimentos com materiais perfurocortantes, que facilitarão a entrada de agentes infecciosos.

Segundo Sisinno (2000), alguns estudos realizados no Brasil com catadores de lixo indicam que os maiores problemas de saúde neste grupo são os seguintes: distúrbios intestinais, parasitoses intestinais, hepatite, doenças de pele, respiratórias e danos nas articulações.

Conforme Minayo-Gómez \& Thedim-Costa (1999: 412), as implicações de saúde afetam particularmente o grande contingente de excluídos e os segmentos mais vulneráveis do mercado informal. Dentre estes:

Os que exercem atividades com expressivo impacto nas taxas de morbi-
mortalidade, não contempladas nos estudos sobre o trabalho informal, por
razões que vão desde a falta de reconhecimento social a seu caráter de
ocupação à margem da legalidade (...) força de trabalho atomizada,
desprotegida socialmente, por cujo infortúnio ninguém parece ser
responsável, restando-lhes apenas soluções individuais.

Para o setor saúde, este novo contexto representa um desafio enorme que o obriga a revisar, de forma permanente, a situação de deterioração ambiental e sua repercussão sobre a qualidade de vida das comunidades. Conforme Leff (2001), a qualidade de vida depende da qualidade do ambiente e está associada a formas inéditas de identidade, de cooperação, de solidariedade, de participação e de realização. Ele ressalta que a degradação ambiental está diretamente associada à deterioração das condições sociais nas quais se produzem e propagam novas epidemias e doenças da pobreza. Sem dúvida, uma das características fundamentais do fomento da saúde pública para o próximo milênio será a necessidade de que se adotem novas estratégias sob uma perspectiva ambiental muito mais definida (OPAS, 2000), principalmente no que se refere à atividade desenvolvida pelos trabalhadores de resíduos recicláveis. 


\section{REFERENCIAL TEÓRICO}

\subsection{RACIONALIDADE AMBIENTAL}

Para que se conseguisse alcançar os objetivos propostos por este estudo em questão, utilizou-se também o autor Enrique Leff, como um norteador tanto para categorizar os depoimentos de maneira relevante e coerente quanto para poderem ser analisados e discutidos. A escolha deste autor, como referencial teórico mais expressivo desta pesquisa, ocorreu devido ao fato de que o mesmo aborda a questão da racionalidade ambiental, e mais especificamente, a racionalidade instrumental e a cultural, que fazem parte da construção deste trabalho.

Segundo Leff (2001), a racionalidade ambiental não é a expressão de uma lógica, mas o efeito de um conjunto de interesses e de práticas sociais que articulam ordens materiais diversas "que dão sentidos e organizam processos sociais através de certas regras, meios e fins socialmente construídos". A racionalidade "ambiental" é, afinal, apresentada como "social". Para ele, a categoria de racionalidade ambiental não só é útil para sistematizar os enunciados teóricos do discurso ambiental, mas também serve para analisar seu potencial e coerência em sua expressão no movimento ambientalista. Neste sentido, a construção de uma racionalidade ambiental depende da constituição de novos sujeitos que objetivem através de sua mobilização e concretizem em suas práticas os princípios e potenciais do ambientalismo. Com relação a isto, correlaciona-se os trabalhadores de resíduos recicláveis como sendo possíveis sujeitos sociais.

Leff ressalta que a racionalidade ambiental é construída mediante a articulação de quatro esferas de racionalidade: racionalidade substantiva; teórica; instrumental e cultural. Para este estudo em específico, analisaram-se os depoimentos baseados na racionalidade cultural e instrumental. Leff (2001) descreve estas duas racionalidades a seguir:

a) uma racionalidade instrumental, que produz os vínculos funcionais e operacionais entre os objetivos sociais $\mathrm{e}$ as bases materiais do desenvolvimento sustentável. A racionalidade instrumental estabelece os meios que conferem sua eficácia à gestão ambiental, incluindo as 
tecnologias ambientais e ecotécnicas, as ordenações jurídicas, os instrumentos legais e os arranjos institucionais das políticas ambientais, bem como as formas de organização do movimento ambiental para gerar as forças sociais necessárias para transformar a racionalidade econômica dominante.

b) uma racionalidade cultural, entendida como um sistema de significações que produzem a identidade e a integridade internas de diversas formações culturais, que dão coerência a suas práticas sociais e produtivas; estas estabelecem a singularidade de racionalidades ambientais heterogêneas que não se submetem a uma lógica ambiental geral e que cobram sentido e realidade no nível das ações locais. A racionalidade cultural multiplica e diversifica as formas racionais de aproveitamento dos recursos de uma comunidade para satisfazer suas necessidades fundamentais e sua qualidade de vida. Neste sentido, a racionalidade cultural organiza e confere sua especificidade ao processo de mediação entre a sociedade e a natureza, entre as técnicas de produção e as normas de aproveitamento dos recursos naturais.

Estas tiveram relevância, pois deram o aporte necessário para sistematizar, categorizar e analisar as falas dos entrevistados. 


\section{MATERIAL E MÉTODOS}

\subsection{TIPO DE ESTUDO}

No intuito de compreender as relações que os trabalhadores separadores de resíduos desenvolvem entre o seu trabalho e o ambiente; entre o seu trabalho e a saúde e de identificar de que maneira estes compreendem o seu trabalho como um processo pedagógico ambiental, utilizou-se uma metodologia caracteristicamente qualitativa de caráter descritivo-exploratório como forma de captar o ponto de vista dos separadores de resíduos no desenvolver de suas atividades.

\subsection{CENÁRIO DA PESQUISA}

A pesquisa foi realizada em uma associação de resíduos recicláveis, situada no bairro Castelo Branco II do município de Rio Grande. O bairro Castelo Branco II (CBII, Rio Grande, RS) é um bairro muito pobre situado na vizinhança imediata do Campus Carreiros da Universidade Federal do Rio Grande (FURG). Originou-se da união de diversas famílias, que, por não terem condições financeiras para pagar aluguel ou comprar terreno, somaram esforços e decidiram lutar por um lugar para morar. Em março de 1995, resolveram instalar-se num terreno desocupado há vários anos na Rua $1^{\circ}$ de Maio, sendo este favorável à ocupação, já que não possuía nenhuma função social. A partir da ocupação por dez famílias, outros grupos também começaram a chegar e instalaram-se na área. Esta ocupação chegou a totalizar 257 famílias. Mais tarde, vieram, a saber, que aquele terreno era de propriedade da Empresa Aliança da Bahia S/A (SP). Então, conforme acordo firmado na Justiça, os ocupantes deveriam deixar o local até 30 de abril de 1996, transferindo-se para o bairro CB II, localizado na periferia da cidade de Rio Grande. A prefeitura comprometeu-se em preparar a infra-estrutura da área a eles destinada (VELASCO, 2003).

A ASTARR (Associação dos trabalhadores em Resíduos Recicláveis) é composta por 11 membros e surgiu em 1999, primeiramente no local do lixão 
municipal de Rio Grande, e está na atual sede desde 2004, após ocorrer o fechamento do lixão municipal em decorrência das mortes ocorridas naquele local. $\mathrm{Na}$ atual sede, cedida pela prefeitura, funcionava a associação do bairro Castelo Branco II, e, segundo o próprio presidente da ASTARR, estava em desuso pelos moradores da comunidade.

O primeiro contato com esta associação demonstrou pontos positivos no sentido de que a mesma possuía um galpão coberto e fechado, protegido do sol, chuva e frio, com médio espaço para circulação dos associados e dos caminhões, apresentando resíduos separados e compactados, empilhados de uma forma segura. Também disponibilizava um banheiro coletivo e mais uma peça para realizar as refeições. Já os pontos negativos encontrados foram: a iluminação não adequada, assim como a circulação de ar, além disso, os separadores realizavam suas atividades sem utilizar nenhum equipamento de proteção.

\subsection{PARTICIPANTES DO ESTUDO}

Elegeram-se como informantes aqueles trabalhadores que se ocupavam da separação de recicláveis na associação no momento da pesquisa. Optou-se por trabalhar com uma amostra de oito trabalhadores separadores de resíduos, escolhidos aleatoriamente, não contemplando crianças e adolescentes menores de 18 anos. O motivo de serem apenas oito, e não os onze associados foram pelo fato de que um estava com problemas de saúde e os outros dois não foram encontrados no local de trabalho. Todos deveriam, necessariamente, estar ligados àquela associação de trabalhadores de resíduos recicláveis em Rio Grande.

\subsection{COLETA DE DADOS}

Realizaram-se jornadas de observação livre, com base num acompanhamento direto e intensivo, valendo-nos de entrevistas semi-estruturadas, de forma a prevalecer à espontaneidade e à informalidade durante as conversas, bem como a não indução de respostas. Para melhor compreender a situação em 
estudo, utilizou-se também de um diário de campo, no qual se registrou todos os fatos considerados relevantes não colhidos pelas técnicas utilizadas.

As entrevistas foram realizadas de forma individual, com autorização expressa de cada participante, seguindo orientações técnicas do comitê de ética em pesquisa, e utilizou-se um gravador. As transcrições dos depoimentos dos entrevistados foram digitadas na integra, com autorização dos participantes, preservando-se o anonimato dos mesmos. Após, realizou-se um refinamento da linguagem falada para uma versão escrita, por meio da exclusão de equívocos de linguagem gramatical. Esse procedimento permitiu a apresentação dos depoimentos com o sentido original construído pelo sujeito da fala na relação com o propósito deste texto acadêmico.

Durante o período dos depoimentos, os dados foram coletados através das entrevistas semi-estruturadas, contendo 19 perguntas descritivas, que se encontram em apêndice 1 , sendo que também se utilizou da observação, concomitante com as 8 entrevistas. Segundo Pádua (2004), a observação é uma técnica de coleta de dados para conseguir informações que utiliza os sentidos na obtenção de determinados aspectos da realidade. A coleta de dados foi realizada entre os meses de fevereiro e março de 2008.

\subsection{ORGANIZAÇÃO E ANÁLISE DOS DADOS}

Os dados foram analisados através da ordenação dos mesmos. Segundo Minayo (1999), neste momento se faz o mapeamento de todos os dados obtidos no trabalho de campo. Aqui estão envolvidas as transcrições das gravações, releitura do material, organização dos relatos e dos dados da observação.

Durante a sistematização das entrevistas, realizou-se inicialmente a leitura livre das transcrições, anotando-se as primeiras interpretações em relação ao tema estudado. Em seguida, procedeu-se à categorização interna das mesmas, onde foram reunidas e ordenadas as respostas de maneira que contemplassem os objetivos deste estudo. Em seguida, os resultados obtidos foram organizados de acordo com as seguintes categorias: 


\begin{tabular}{|c|c|c|c|}
\hline Categorias & Racionalidade Cultural & $\begin{array}{c}\text { Racionalidade } \\
\text { Instrumental }\end{array}$ & $\begin{array}{c}\text { Relações entre trabalho e } \\
\text { saúde }\end{array}$ \\
\hline \multirow{5}{*}{ Subcategorias } & $\begin{array}{l}\text { Relação trabalho e Meio } \\
\text { Ambiente. }\end{array}$ & \multirow{5}{*}{$\begin{array}{l}\text { Processo } \\
\text { pedagógico } \\
\text { ambiental. }\end{array}$} & $\begin{array}{l}\text { O uso de Equipamentos de } \\
\text { Proteção. }\end{array}$ \\
\hline & $\begin{array}{l}\text { Relação Trabalho e } \\
\text { comunidade. }\end{array}$ & & $\begin{array}{l}\text { Riscos/Perigos no } \\
\text { desenvolver de seu } \\
\text { Trabalho. }\end{array}$ \\
\hline & \multirow{3}{*}{$\begin{array}{l}\text { Relação trabalho e } \\
\text { renda. }\end{array}$} & & Trabalho e ferimentos. \\
\hline & & & $\begin{array}{l}\text { Mudanças para melhorar a } \\
\text { saúde no trabalho. }\end{array}$ \\
\hline & & & $\begin{array}{l}\text { Mudanças para melhorar a } \\
\text { saúde no ambiente. }\end{array}$ \\
\hline
\end{tabular}




\section{RESULTADOS E DISCUSSÕES}

Partindo-se da idéia de que a construção de uma racionalidade ambiental depende da constituição de novos sujeitos que objetivem através de sua mobilização e concretizem em suas práticas os princípios e potenciais do ambientalismo, utilizouse a Racionalidade Cultural e a Racionalidade Instrumental, de Enrique Leff, para demonstrar de que forma estão constituídas na relação entre o trabalho, ambiente e saúde destes trabalhadores separadores de resíduos. Estes trabalhadores pesquisados totalizaram-se em oito pessoas, das quais sete eram do sexo masculino e uma do sexo feminino com idades variando de 18 a 60 , sendo que a escolaridade dos mesmos era, predominantemente, de semi-analfabetos ou com ensino fundamental incompleto.

\subsection{RACIONALIDADE CULTURAL}

A racionalidade cultural é entendida como um sistema de significações que produz a identidade e integralidade de cada cultura, dando coerência as suas práticas sociais e produtivas em relação às potencialidades de seu entorno geográfico e de seus recursos naturais (LEFF, 2001).

A análise desta categoria está dividida em subcategorias, são elas: a questão da relação entre $\circ$ trabalho e meio ambiente; a relação trabalho $\mathrm{e}$ comunidade, e por fim a relação trabalho e geração de renda. Em cada uma destas são apresentadas algumas significações, as quais os separadores de resíduos compreendem como sendo relevantes.

\subsubsection{Relação trabalho e Meio Ambiente}

Segundo Reigota (2002, p. 14) meio ambiente é:

O lugar determinado ou percebido, onde os elementos naturais e sociais estão em relações dinâmicas e em interação. Essas relações implicam 
processos de criação cultural e tecnológica e processos históricos e sociais de transformação da natureza e da sociedade.

Para Leff (2001), o conceito de ambiente surge como uma nova visão do desenvolvimento humano, que reintegra os valores e potenciais da natureza, as externalidades sociais, os saberes subjugado e a complexidade do mundo, negados pela racionalidade mecanicista, simplificadora, unidimensional e fragmentadora que conduz o processo de modernização.

Ainda, o ambiente emerge como um saber reintegrador da diversidade, de novos valores éticos e estéticos e dos potenciais sinergéticos gerados pela articulação de processos ecológicos, tecnológicos e culturais (LEFF, 2001).

Os entrevistados relacionam o seu trabalho e o meio ambiente, quanto a racionalidade cultural, como associada à significação de limpeza. Isto se observa a seguir:

Limpa a cidade, evita a poluição também. (Entrevistado $\left.n^{\circ} .5\right)$

Limpa as ruas não deixa muita sujeira. Não estamos sujando o meio ambiente, estamos reciclando, não estamos poluindo o meio ambiente. (Entrevistado $\mathrm{n}^{\circ} .3$ )

Não estamos poluindo o meio ambiente. (Entrevistado $n^{\circ} .6$ )

Eu acho importante pelo seguinte, retira um monte de lixo da rua isso. Quando tu vês, largam plásticos, essas sacolas de mercado, entopem tudo que é bueiro, e se largam garrafas muito pior. (Entrevistado $\mathrm{n}^{\circ}$. 8)

Nestes trechos das falas, evidencia-se, primeiramente, o significado que os separadores fazem com relação ao seu trabalho e ao meio ambiente, o qual está ligado à questão de limpeza, manter o bairro mais limpo, ou seja, percebe-se o quanto, para eles, à poluição, principalmente no que se relaciona aos resíduos sólidos está diretamente associada ao espaço de vida. Conforme Rancura (2005), as constantes ocorrências inadequadas de resíduos sólidos em áreas consideradas impróprias constituem uma realidade, que a cada dia, torna-se mais freqüente no Brasil, causando poluição do solo, água e ar.

Estes separadores conseguem associar que, através de seu trabalho, eles desempenham um papel importante no local que residem, pois se tornam responsáveis pela limpeza do município, como cita o entrevistado a seguir:

Claro, é importante para todo mundo, todos que reciclam estão cooperando hoje, do jeito que vai o mundo, temos que fazes isso aí, se não fizer isso aí tu já viu. É bom juntar porque diminuem muito o acúmulo de resíduos atirados nas ruas. Isso aqui antes em cada valeta tinha 20,30 garrafas, 
depois que eu abri a reciclagem, a recicladora diminuiu $100 \%$. Eles trazem, a gente compra deles. Um fardo daqueles ali tem 2.600 garrafas, agora tu colocas aquelas 2.600 garrafas cheias em cima de um lixão para ver o que acontece, coloca na rua para ver o tamanho do volume que faz. (Entrevistado $\mathrm{n}^{\circ} .1$ )

De acordo com Leff (2001), os saberes técnicos e as práticas tradicionais são parte indissociável dos valores culturais de diferentes formações sociais. Constituem recursos produtivos para a conservação da natureza e capacidade própria para a autogestão dos recursos de cada comunidade. Neste sentido, os separadores fundamentam suas práticas de acordo com o que é projetado para eles com relação ao meio ambiente que os envolve, que neste caso é a questão da disposição dos resíduos no ambiente sem ter uma utilização dos mesmos.

Ainda, o entrevistado consegue relacionar o quanto, após ter iniciado o trabalho de separação dos resíduos, houve uma diminuição no acúmulo, principalmente das garrafas de plásticos, nas ruas da comunidade. Compreende, através de seu trabalho, que pode ajudar a melhorar o ambiente que o envolve, e conforme Leff (2001) é nas comunidades de base e em nível local que os princípios do ambientalismo tomam todo o seu sentido como potencial produtivo, formando significados e valores culturais capazes de modificar o agir e o pensar daqueles moradores.

A seguir, surgem outros sentidos na realização da separação dos resíduos.

Ah, acho importante porque a gente cuida do meio ambiente no caso, se recicla um monte, um monte de coisas no caso que, fica ai atirado, ai a gente recicla. (Entrevistado $n^{\circ} .7$ )

Feitosa (2006) compreende que a atividade de separação pode ser tida como uma forma de cuidar o ambiente, porque, ao recolher os resíduos, os recicladores estão contribuindo para o controle da degradação ambiental, para a recuperação das potencialidades perdidas do ecossistema, favorecendo nossa sobrevivência.

É o trabalho, a gente se sente bem, porque a gente ajuda um pouco a limpar a cidade, a gente ajuda a limpar, separa o lixo, deixa mais limpo. $O$ lixão ali já não tem muito, não tem capacidade já tá quase cheio ali, a gente ajuda diminuir o excesso. (Entrevistado $n^{\circ}$. 6)

Através desta falas, nota-se à introdução de outros significados na atividade realizada pelo entrevistado. Conforme o entrevistado $n^{\circ}$. 7 , ele diz se identificar 
como sendo uma pessoa que cuida do meio ambiente, cuidar este que está relacionado com a reciclagem, a qual acaba por incluí-lo na questão ambiental, tornando-o como zelador deste ambiente. E mais, como cita o entrevistado $\mathrm{n}^{\circ}$. 6 , a atividade da reciclagem envolve este ator social de tal maneira que o mesmo sentese bem realizando tal atividade.

Estão, desta maneira, associando sua satisfação em querer manter o meio ambiente mais limpo, através da reciclagem, possibilitando colocar em prática o princípio da racionalidade ambiental, que além de se construir numa inter-relação permanente da teoria e da prática, também se funda numa nova ética que se manifesta em comportamentos humanos, em princípios de uma vida democrática com valores culturais que dão sentido à existência humana, os quais se traduzem num conjunto de práticas sociais que transformam as estruturas do poder associadas à ordem econômica estabelecida, mobilizando um potencial ambiental para a construção de uma racionalidade social alternativa (LEFF, 2001), que neste caso objetiva-se através da conscientização, pelos trabalhadores recicladores de resíduos, quanto à importância de se realizar a reciclagem dos resíduos.

Para o meio ambiente é uma boa, nasce planta, tu começas a colocar só
lixo, não nasce nada, não nasce planta, e para o meio ambiente é uma boa
conserva. Mas com a reciclagem melhora muita coisa! Se cada bairro
fizesse alguma coisa para reciclar, melhorava a vida de todo mundo.
(Entrevistado $\mathrm{n}^{\circ}$. 3)
Como é que eu vou dizer assim, estamos evitando, o desmatamento, nós
estamos evitando contaminação do solo, tudo isso o reciclador está
evitando. Porque aqui é o seguinte: cada $1.000 \mathrm{~kg}$ de papel que a gente
recicla, a gente está deixando de corta 200 árvores. E em cada 1.000
garrafas que fica no solo, são 150 anos no mínimo para se desmancharem.
(Entrevistado $\mathrm{n}^{\circ}$. 1)

Para estes entrevistados, surgem outros significados da prática de seu trabalho com relação ao meio ambiente. Eles aparecem com uma visão mais ecológica, no qual o desenvolver de seu trabalho está interligado ao sentido de evitar o desmatamento, de preservar plantas, de não contaminar os solos. Conforme Rouquayrol (2003), os gases provenientes das áreas de decomposição dos resíduos apresentam conseqüências diretas nas plantas, pois devido aos seus efeitos fitotóxicos, causam a morte da vegetação da área de disposição e adjacências, devido à depleção do oxigênio na zona radicular das plantas, podendo migrar até uma distância de $1.500 \mathrm{~m}$. 
Esta significação fica evidente, quando o entrevistado $n^{\circ} .1$ cita ter obtido conhecimento acerca do seu trabalho e do benefício que o mesmo proporciona ao meio ambiente. Neste sentido, a racionalidade cultural organiza e confere sua especificidade ao processo de mediação entre a sociedade e a natureza, entre a técnica de produção e suas normas de aproveitamento dos recursos naturais (LEFF, 2001), caso contrário, se o desenvolver de seu trabalho para o meio ambiente não apresentasse significado algum para estes entrevistados, certamente eles não se constituiriam como possíveis sujeitos, pessoas preocupadas com questões sociais que envolvam a comunidade no seu entorno.

Para os entrevistados a seguir, há uma relação direta entre a realização da reciclagem e o surgimento de doenças.

Evita doenças, a reciclagem evita um monte de doença, é uma boa para o pessoal. (Entrevistado $n^{\circ} .3$ )

A grande importância, a grande meta é deixar mais limpo o bairro para não proliferar doenças. (Entrevistado $n^{\circ}$. 6)

Aqui se evidencia como significado, a questão das doenças que a disposição inadequada dos resíduos pode trazer a comunidade local. Porto (2000) relata que além dos resíduos propriamente ditos, a migração de chorume no solo e na água pode levar ao seu comprometimento através da contaminação por compostos orgânicos e íons metálicos. $O$ chorume ${ }^{14}$, normalmente, surge imediatamente após a disposição e sua presença ocorre durante toda a vida útil da área de disposição, podendo perdurar por décadas.

Conforme Conceição (2005), os aterros de Rio Grande são intensamente contaminados por metais pesados, superando na média, várias vezes os valores aceitáveis, isto é Cádmio -13 vezes, Cobre -28 vezes, Cromo - 2 vezes, Chumbo 146 vezes, Ferro -3 vezes, Mercúrio - 68 vezes, Manganês -3 vezes, Níquel -3 vezes, Zinco - 18 vezes.

\footnotetext{
${ }^{14}$ Segundo Wikipédia, significa o líquido poluente, de cor escura e odor nauseante, originado de processos biológicos, químicos e físicos da decomposição de resíduos orgânicos. Esses processos, somados com a ação da água das chuvas, se encarregam de lixiviar compostos orgânicos presentes nos aterros sanitários para o meio ambiente. Esse líquido pode atingir os lençóis freáticos, de águas subterrâneas, poluindo esse recurso natural. A elevada carga orgânica presente no chorume faz com que ele seja extremamente poluente e danoso às regiões por ele atingidas.
} 
Para a saúde humana, estes metais pesados podem apresentar as seguintes complicações, como: distúrbios do sistema nervoso, a osteomalácia, a osteosporose; dano ao epitélio gastrintestinal, dermatites, úlceras cutâneas, inflamação nasal, câncer de pulmão, perfuração do septo nasal, sistema cardiovascular, cefaléia e distúrbios emocionais.

Nas falas a seguir, surgem indícios relacionados à questão da consciência ambiental, pois a mesma implica na busca e na consolidação de novos valores na forma de ver e viver no mundo, a partir da complexidade ambiental, que possibilita a construção de novos padrões cognitivos na relação homem/natureza, a fim de mover o processo criativo humano para gerir novas possibilidades diante dos fenômenos da vida e da sobrevivência a partir da sinergia existente no tecido social, ambiental e tecnológico (LEFF, 2001).

Eu me sinto assim uma pessoa útil tentando ajudar a minha cidade, porque
isso ai eu estou ajudando a limpar a cidade, coisa que o governo não estão
fazendo direito, e ajudando as pessoas que querem ganhar algum dinheiro.
Limpando o meio ambiente, porque nós precisamos limpar o meio ambiente
para o futuro, que se a gente não fizer isso como é que vai ficar? Vai ficar
tudo contaminado, não vamos ter mais nada, vai ser só lixo, lixo e lixo. Eu
não posso ver uma garrafinha na rua que eu já coloco em um lixo, que é
para o próximo coletar. Tu vai entupir um esgoto e vai ficar ruim. Então é
essa a iniciativa minha própria, de limpar, ajudar a limpar o meio ambiente,
ajudar a rua, ajudar um reciclador que vem ali pegar a garrafinha que eu
deixei. (Entrevistado $n^{\circ}$. 2)

Pelas falas decorrentes deste entrevistado, como representante do grupo de trabalhadores, pode-se evidenciar que o mesmo apresenta mais de um significado na relação trabalho-meio ambiente, ou seja, o mesmo percebe-se útil no sentido de estar associando a sua prática profissional às questões como limpeza da cidade, renda aos trabalhadores e melhor qualidade de vida. Percebe-se que além de estar ajudando o meio ambiente, ele se preocupa com outros recicladores, que ao invés de ignorar um reciclado no ambiente, ele disponibiliza este a outros colegas de profissão. Evidencia-se aqui um sentido de cooperação, que conforme Porto (2000) significa trabalhar junto, tendo como objetivo uma intenção explícita de somar algo criar alguma coisa nova ou diferente através da colaboração.

O sentido coletivo da ação individual está presente nos depoimentos dos entrevistados, como pode ser observado nos depoimentos. Este sentido está diretamente relacionado à maneira como se compreende, age e se relaciona no e 
com o meio. A utilidade da ação individual, ou seja, a percepção do estar sendo útil ao coletivo, está inevitavelmente ligada ao conjunto de valores da sociedade a que se pertence. E este conjunto de valores é estabelecido nas relações de proximidade entre eu e o outro, isto é, ser humano e natureza.

Afinal, o próprio conceito de natureza é um valor definido nos processos históricos e culturais vividos pelos sujeitos sociais. Cada grupo percebe e interage com o meio de uma forma. Os aspectos que compõem a definição de meio ambiente são valorados de acordo com os contextos em que são considerados (LEFF, 2001).

A consciência ambiental é estruturada, na atualidade, sobre fatos reais e confiáveis, que neste estudo em particular ficou expresso para a maioria dos sujeitos, através da problemática dos resíduos sólidos.

Nas falas dos trabalhadores separadores de resíduos (lixo), consegue-se visualizar o quanto eles apreendem o suporte de ajuda produzido por eles, para a melhoria do meio ambiente, seja este ambiente local, como o bairro, a cidade, ou até mesmo global. Eles compreendem uma potencialidade que este entorno geográfico (o ambiente para eles) tem quando se torna adequado à vida em comunidade, a partir da sua disponibilidade em condições de limpeza. Esta disponibilidade é referida sempre na relação com a realização da separação de resíduos, que eles desenvolvem diretamente na comunidade.

$\mathrm{Na}$ análise das entrevistas, a formação de uma consciência ambiental pode estar relacionada, predominantemente, ao conhecimento adquirido por meio do saber do ambiente na relação com a transformação e utilização dos resíduos sólidos.

Esse cidadão, ambientalmente consciente, deve possuir o compromisso da formação dessa consciência para gerações futuras, através de ações de educação ambiental e social, além de exercitar as atitudes e os comportamentos próambientais, de maneira a preservar e melhorar cada vez mais o meio ambiente que o cerca.

Desta maneira, podem satisfazer suas necessidades básicas e orientam seu desenvolvimento dentro de estilos étnicos e formas diversas de significação cultural. (LEFF, 2001), constituindo-se em sujeitos. No particular, para os entrevistados deste estudo, isto é expresso na relação com ambiente físico-social (cidade, bairro, 
comunidade) e sua atividade produtiva, ou seja, ao se sentirem úteis para si, reproduzem-no para os outros a partir do trabalho.

\subsubsection{Relação Trabalho e comunidade}

Neste segundo tópico, analisam-se questões referentes aos significados apresentados pelos trabalhadores separadores de resíduos em relação a sua comunidade local, no desenvolver de suas atividades. Para isto, indagou-se sobre como eles se sentiam vistos pela comunidade local.

É, por um lado à gente está fazendo um benefício para a humanidade, por
outro eles acham que a gente é lixeiro, que a gente não sabe definir uma
coisa da outra, e hoje tudo é profissão, não interessa, As pessoas não
entendem que a gente está reciclando o que eles colocam fora!
(Entrevistado $n^{\circ}$. 1)

Para este entrevistado, a questão de estar beneficiando o ambiente em que vivem todos daquela comunidade é muito significativa. Ele relata que a compreensão que os moradores fazem acerca do seu trabalho, está relacionada à condição de serem apenas lixeiros e não separadores de resíduos sólidos. Conforme Demajorovic (2006) existe uma diferença fundamental entre os termos Lixo e Resíduo Sólido; enquanto o primeiro não possui qualquer tipo de valor, sendo necessário o seu descarte, o segundo pode possuir valor econômico agregado, havendo possibilidade de se estimular o seu aproveitamento dentro de um processo produtivo apropriado. O autor acrescenta, ainda, que esta comparação só pode ser levada em consideração se o lixo for encarado como um material sem nenhuma utilidade. O entrevistado assinala que a comunidade não leva em consideração que a atividade, desempenhada por ele, é uma profissão, e ainda está ajudando aquela comunidade a ter uma melhor qualidade de vida, visto que está evitando a acumulação de resíduos no ambiente, incluindo os descartados pelos próprios moradores.

Para Migueles (2004), o trabalho com o lixo interfere tanto na identificação do catador com o seu trabalho como no reconhecimento da sociedade pelo trabalho desempenhado pelo catador. Já para Gonçalves (2004b), é um grande engano considerar que esses catadores são supérfluos do ponto de vista da acumulação global, porque vivem dos restos da sociedade. Eles se encontram integrados à 
economia, ainda que pela via mais perversa do trabalho socialmente não reconhecido.

Estes trabalhadores referem que, muitas vezes são discriminados perante a comunidade local, por esta não compreender suas práticas, as quais têm influência direta no meio onde vivem os próprios moradores. Uma questão mencionada pelos trabalhadores é o fato dos moradores não saberem diferenciar lixo de resíduos sólidos recicláveis, como surge na fala a seguir.

É alguns criticam, outros apóiam, eles acham que isso aqui é um acúmulo
de lixo que está ocorrendo, e não é! A gente fica só com o que é reciclado.
$70 \%$ achamos favoráveis, acham que tem que fazer, mas ele não sabe o
porquê que tem que fazer, mas tem uma noção que isso prejudica o meio
ambiente. (Entrevistado $n^{\circ} .1$ )

Segundo Migueles (2004), para que a sociedade perceba o catador como outro trabalhador qualquer, é preciso associar o trabalho de catação a significados positivos, pois a população costuma correlacionar o caráter excludente do trabalho do catador ao sentido negativo do lixo. Ainda, pode existir uma concepção, no imaginário coletivo destes separadores, de que o lixo é algo deplorável e descartável, e desta maneira, cria-se uma dificuldade em dispensar-lhe uma utilidade para o mesmo.

O que falta, segundo o entrevistado, é uma compreensão por parte dos moradores com relação à importância de se estar realizando aquela atividade de reciclagem e do quanto isto beneficia o coletivo, ou seja, os moradores, os associados e o ambiente. Este entendimento estaria associado a uma valorização da profissão dos catadores, não sendo vistos pela população como acumuladores de lixos.

Olha, para alguns é bom, mas tem o pessoal que é aquele ditado: têm
alguns que gosta que limpem isso aí, tudo limpinho. Mas têm outros que
nem estão esquentando, largam o lixo em qualquer lugar. Às vezes a
pessoa larga lixo para o lixeiro ali, eles (os cachorros) vem e viram e as
pessoas nem estão esquentando. Ah, acho que a maioria apóia porque,
uma que é para o bem do bairro, se eles não apóiam o que eles vão apoiar.
(Entrevistado $n^{\circ} .4$ )

Mesmo sendo considerada uma atividade pouco valorizada, o entrevistado acredita existir um apoio em relação à reciclagem que eles estão desenvolvendo, pois ela apresenta um significado positivo para os moradores do bairro, que é a questão da limpeza. Esta significação de limpeza para os moradores parece ser um 
ponto de aproximação entre os trabalhadores e a comunidade, pois o interesse é comum - ambiente limpo.

Conforme Leff (2001), isto poderia constituir a atividade de reciclar, como um projeto social fundado na reapropriação da natureza, na ressignificação das identidades individuais e coletivas e na renovação dos valores do humanismo, incluindo outros sujeitos que estariam valorizando a profissão.

É pouca, pouca, pouca, não tem assim, vou te dizer uma coisa assim ó, não tem, são poucas as pessoas que se interessa por este trabalho, são poucas pessoas. Não valorizam, não, é que não, geralmente muitos poucos se importam, muito pouco, apoio é coisa que não tem. (Entrevistado $\mathrm{n}^{\circ}$. 6 )

O reconhecimento da importância de diversos sujeitos como coresponsáveis na gestão de resíduos sólidos, a valorização da atividade de reciclagem e a promoção de ações educativas para mudanças de valores e hábitos da sociedade são alguns dos elementos centrais para a construção de uma consciência ambiental.

Olha, algumas pessoas acham que é bom fazer isto. É, e outros não concordam, não concordam em separar nada. (Entrevistado $n^{\circ} .8$ )

Evidencia-se, através destas falas, que mesmo sendo uma profissão realizada para obter algum sustento, é de certa forma considerada como sendo uma profissão degradante por parte de uma parcela da população, a qual não identifica estes profissionais como pessoas que desempenham um papel importante dentro do sistema econômico, o qual acaba, muitas vezes, externalizando esta parte da população.

Esta externalização significa a exclusão e, mesmo estes separadores exercendo uma atividade, que é amparada por lei como sendo profissão, acaba sofrendo algum tipo de repulsa por parte dos moradores, como cita o entrevistado a seguir.

Ih, tem uns que mexem, tem outros que dão conselho, eu nem dou bola. Assim, como é que eu vou te dizer: é trabalhando no lixo, mexendo nas fraldas. Mas a gente só mexe em plástico. Escuracha o cara! Meus amigos lá falam: o importante é estar trabalhando! (Entrevistado $n^{\circ} .3$ )

Tais catadores vivem, na verdade, um processo de exclusão/inserção social, já que suas vidas são permeadas por zonas de vulnerabilidades, fragilidades e precariedades (GONÇALVES, 2004b). 
Dessa forma, pode-se inferir que o separador de materiais recicláveis é incluído ao ter um trabalho, mas excluído pelo tipo de trabalho que realiza trabalho precário, realizado em condições inadequadas, com alto grau de periculosidade e insalubridade, sem reconhecimento social, com riscos, muitas vezes, irreversíveis à saúde.

Para Oliveira (1998), rigorosamente os únicos realmente excluídos seriam aqueles de quem já não se pudesse extrair nenhum centavo de mais-valia. Este é o caso, por exemplo, dos catadores que reviram o lixo, buscando apenas restos de comida para a alimentação própria e dos demais familiares.

Como cita o entrevistado $n^{\circ} .5$ :

Ah, no início como um lixeiro, mas depois eles mesmos começaram a
reciclar, viram que dava pra se safar, tiravam um dinheiro para a família,
para o sustento. $30 \%$ mudaram a opinião e estão até reciclando. Antes era
uma crítica, chamavam de lixeiro, não era um trabalho digno.

Estes separadores de resíduos, através da reciclagem estão buscando uma forma de inserção no mundo social e do trabalho, realizando uma atividade muito importante para a sociedade e o meio ambiente, pois através da mesma, estão impedindo a contaminação do solo, a proliferação de certas patologias. Aparecem como sujeitos indispensáveis no sistema produtivo capitalista, pois recolocam, à disposição do sistema econômico vigente, matérias primas para diversos produtos.

Através da separação dos resíduos, incluíram-se novos sujeitos nesta atividade produtiva, a qual acabou em gerar renda para eles e suas famílias e, de certa forma, modificou os significados que estas pessoas tinham em relação aos resíduos, o qual passou a exercer um papel importante na sua sobrevivência. Diante disso, também se observa a constituição da racionalidade cultural, pois traz significações, produz a identidade e integridade daquelas práticas sociais com relação ao seu ambiente geográfico.

\subsubsection{Relação trabalho e renda}

Como pode ser observado, além da preocupação destes separadores com o meio ambiente, surge em algumas falas, a importância de não só beneficiar o 
ambiente, mas sim beneficiá-los, através da renda gerada por esta atividade. As pessoas que consideram a reciclagem dos resíduos como um meio de gerar dinheiro, tratam de maneira diferente a questão ambiental. Elas assimilam melhor o conceito de reutilizar, de reaproveitar, pelo fato de terem por trás disso uma possibilidade de renda (MARIUZZO, 2007).

Isto se deve como comenta Marx (2004), em o "Capital", como criador de valores de uso, como trabalho útil, é o trabalho, por isso, uma condição de existência do homem, independente de todas as formas de sociedade, eterna necessidade natural de mediação do metabolismo entre homem e natureza e, portanto, vida humana.

Trabalho este que pretende, além de melhorar o meio ambiente, satisfazer as necessidades destes separadores, pois precisam, como qualquer pessoa, de dinheiro para alimentação, vestuário, moradia e lazer.

Neste aspecto, surge no decorrer das falas a seguir, outro significado associado à atividade de reciclar, que é a questão da renda, e a importância que os mesmos depositam em seu trabalho.

Se cada bairro fizesse uma coisa para reciclar, melhorava a vida de todo mundo. Uma que dava para tu vender, arrumar dinheiro, sustentar uma família e melhorava o meio ambiente (Entrevistado $\mathrm{n}^{\circ}$. 8).

É importante porque eu estou ganhando e estou ajudando a não poluir tanto. (Entrevistado $n^{\circ} .4$ )

Ajudando o meio ambiente e ajudando algumas pessoas que querem ganhar alguns trocados, por que isso é uma associação, tudo o que é vendido aqui é ratiado entre as pessoas que trabalham aqui! (Entrevistado $\left.n^{\circ} .2\right)$

Pelo motivo de eu sustentar uma família eu me sinto realizado, e também pelo meio ambiente, que não suja, não polui tanto. (Entrevistado $n^{\circ} .5$ )

Os entrevistados perceberam que, através desta atividade, existe a possibilidade de conseguir ganhar algum dinheiro, ajudando ao associado e também no sustento da sua família. Porém, muitos associados dizem que gostariam de desempenhar a atividade de reciclagem, com esta associação, no antigo local, o lixão municipal. Afirmam que lá, o ganho em questão financeira era muito maior, sendo que também existia a oportunidade de contemplar mais pessoas nesta atividade, o que não acontece na atual associação. 
Eu gostaria se o local que nós trabalhávamos fosse reaberto de novo, o lixão no caso, que diminuiu só nessa comunidade $60,70 \%$ do comércio e do dinheiro rodado. $60 \%$ caíram todo o comércio, muitos fecharam também, porque muitos eram, sobreviviam dos comércios dali, que era muito dinheiro que girava, e fora o que vai ser enterrado ali, poluindo o solo, poluindo tudo. Isso aí o meio ambiente e a FEPAM não enxergam. Tem bastante trabalho, como eu falei, fechou ali e muitos estão presos porque não tinham outra coisa para fazer, não tinha escolaridade, não davam serviço, aí voltaram a roubar. (Entrevistado $n^{\circ} .5$ )

Para sustentar a idéia de voltar a funcionar a reciclagem de resíduos no lixão municipal, o entrevistado aborda questões sociais que influenciaram diretamente naquela comunidade, sendo uma destas a geração de renda, as quais beneficiavam muitas, principalmente o comércio local, já que após o fechamento do lixão municipal, muitos comerciários fecharam seus estabelecimentos, pois dependiam do dinheiro oriundo daquela atividade. Outro ponto importante está relacionado ao aumento na prática de roubos, ocasionando a prisão de alguns catadores, impossibilitando os mesmos de contribuir para o sustento de seus familiares. Isto ocorreu, segundo o entrevistado, devido a estes recicladores não encontrarem outra atividade para adquirir suas rendas, pois dominavam a função de recicladores de resíduos.

Além disso, aparece um aspecto relevante nestas falas, que é a baixa escolaridade destes. Por não atingirem um patamar aceitável que proporcione alguma chance de competir por vagas no mercado de trabalho, acabam não tendo outra opção a não ser de realizar a reciclagem. Isto é evidenciado nesta pesquisa, no qual dos oito entrevistados, apenas dois possuíam o ensino fundamental completo, e os outros seis o ensino fundamental incompleto.

Acaba sendo a atividade de reciclagem, uma alternativa para muitas destas pessoas, a qual gera certa renda, propiciando o sustento de suas famílias. Isto é relatado na fala a seguir.

Nós temos um lixão que comporta, comportava, atendendo direta e indiretamente mais de 500 famílias trabalhando, tirando o lixo, tirando o sustento de cada família! Porque que o nosso prefeito deixa aquele lixão do jeito que está, acumulando um monte de lixo! (Entrevistado $n^{\circ} .2$ )

Conforme estas falas, um dos caminhos que eles visualizam para conseguir solucionar, não apenas a questão ambiental, mas principalmente a questão financeira dos moradores do próprio bairro, seria a volta da associação no lixão municipal. De acordo com o entrevistado $\mathrm{n}^{\circ}$. 2, a atividade de catação de resíduos 
no lixão atendia direta e indiretamente em torno de 500 famílias que sobreviviam exclusivamente da atividade no lixão. Esta constatação é muito relevante, pois traz novamente significados da catação, associados aos aspectos sociais, como a geração de renda e a sustentabilidade familiar para aquela comunidade. $E$ mais, tal atividade estaria apresentando-se como uma solução ambiental, pois estariam realizando a reciclagem, evitando o acúmulo de resíduos daquele local. Contudo, para que ocorresse a volta desta atividade no lixão deveria existir, conforme Leff (2001), certa coerência a suas práticas sociais e produtivas em relação às potencialidades de seu entorno geográfico e de seus recursos naturais, ou seja, diálogo com a comunidade no sentido de abordar questões sócio-ambientais para emergir uma consciência ambiental dos envolvidos, pois o autor ressalta ainda que a partir desta consciência, são gerados novos princípios, valores e conceitos para uma nova racionalidade produtiva e social, além de projetos alternativos de civilização, de vida e de desenvolvimento.

Neste sentido, conforme as falas a seguir, os entrevistados dizem possuir projetos, elaborados por eles, que poderiam ser utilizados para promover a atividade de reciclagem dos resíduos naquele local.

Ali é dinheiro botado fora, dinheiro botado fora, claro, pega uma associação
como é aqui, tu seleciona as pessoas, tu faz um cadastro como já foi feito,
nós temos tudo, nós temos firmas que nos apóiam em qualquer coisa que o
lixão for aberto, nos dão luvas, nos dão EPIs, nos dão tudo! Maquinário,
tudo, para a gente poder trabalhar, mas não tem ajuda da própria política,
não querem ajudar o próprio meio ambiente. Tiraria a contaminação da
nossa lagoa que está contaminada. (Entrevistado no. 2)
Basta ter uma organização como já teve, já ofereceu projetos e não
aceitaram. Não aceitaram nem o projeto. E era um projeto bom! Já fizemos
projeto, já oferecemos, já levamos projeto e mostramos para a televisão (TV
mar, para a RBS), inclusive para o prefeito, para o promotor. Um empurra
para o outro e diz que não podem liberar, devido que o prefeito não pode
por causa de justiça e a justiça não pode por causa do prefeito, um empurra
para o outro, não fazem nada! Era um sustento, mas fecharam, não querem
projeto nenhum, não querem nada, eles não querem é ter trabalho acho,
apesar de que trabalho, eles não iriam ter só aceitar o projeto e nós
mesmos si ajudava à comunidade. Unia-se, a pessoa unida.... (Entrevistado
$n^{\circ}$. 5)

Demonstra-se o anseio por parte destes entrevistados à volta da atividade naquele lixão, pois como relata o entrevistado $n^{\circ}$. 5, aquele local proporcionava "sustento", beneficiando muitos moradores do bairro. Outro ponto interessante que ele ressalta é que eles, associação, iriam ajudar a comunidade na forma de união. 
Conforme Leff (2001) existe a possibilidade de ser uma gestão ambiental participativa, pois propõe, além da oportunidade de reverter os custos ecológicos, neste caso o montante de resíduos acumulados e sem reutilização, além dos custos sociais, apresentados aqui como o desemprego, roubos, analfabetismo, a possibilidade de integrar a população marginalizada num processo de produção para satisfazer suas necessidades fundamentais, aproveitando o potencial ecológico de seus recursos ambientais, respeitando suas identidades coletivas.

Concordando com Leff (2001), quando ressalta que os princípios de gestão ambiental e de democracia participativa seria propor a necessária transformação dos Estados nacionais e da ordem internacional para uma convergência dos interesses em conflitos e dos objetivos comuns dos diferentes grupos e classes sociais em torno do desenvolvimento sustentável e da apropriação da natureza, torna-se imprescindível há existência de uma forma de comunicação realmente eficaz, no qual possa debater as questões inerentes àquela comunidade. Neste caso estariam relacionadas estas questões à reciclagem dos resíduos, que além de proporcionar uma reutilização daquilo que seria posto fora, podendo agredir e contaminar o ambiente, afetando diretamente a comunidade local, venha a contribuir para fornecer uma forma de renda as pessoas desempregadas, pois pela falta de uma perspectiva de conseguir outro emprego, trabalhavam e dependiam exclusivamente da separação de resíduos.

\subsection{RACIONALIDADE INSTRUMENTAL}

Conforme Leff (2001), a Racionalidade Instrumental é aquela que requer instrumentos técnicos que traduzem os propósitos do desenvolvimento sustentável em ações, programas. Mobiliza os sujeitos sociais para promover as mudanças políticas e sociais que permitam a emergência e operatividade desta racionalidade. Nesta categoria, a análise divide-se em dois momentos. O primeiro refere-se aos associados realizarem algum movimento social, reuniões, palestras em prol da divulgação da importância da reciclagem, e se esta ação está direcionada em realizar mudanças políticas e sociais no entorno da sua localidade. É possível compreender, a partir dos depoimentos, que tipos de movimentos estes 
trabalhadores desenvolvem para tentar formar alianças em torno de objetivos comuns, no caso desta pesquisa, a reciclagem dos resíduos.

Em um segundo momento, apresenta-se as falas de alguns entrevistados que demonstram indícios de realizar o processo pedagógico ambiental com os moradores daquele bairro. Esta parte da análise também é relevante, pois emerge neste contexto o surgimento de novos valores e conhecimentos, vinculado à transformação da realidade para construir uma formação ambiental.

Inicia-se a análise com a questão da existência ou não de movimentos. Para isto, os trabalhadores foram questionados sobre a realização de algum tipo de reunião para discutir os seus problemas com a comunidade local, obtendo as seguintes respostas:

Não, aqui não. Aqui são tudo meio por fora, não se interessam. Nem a associação se mete nisso. Associação nunca fez nada sobre reciclagem, nada. A associação fica nos fundo aqui da igreja. (Entrevistado $n^{\circ} .1$ )

Não, apoio não! Eles (associação) não procuram, não sei se é por vaidade porque a gente concorreu com eles na eleição, nós também tínhamos uma chapa, então eles fazem o trabalho deles e a gente o nosso. (Entrevistado $\left.\mathrm{n}^{\circ} .6\right)$

Nestas duas respostas, analisa-se que não existe nenhum incentivo ou apoio por parte da associação do bairro, apesar de os entrevistados colocarem que a associação de bairro não os procura. Um dos motivos, conforme o entrevistado $n^{\circ}$. 6 seria a questão de "vaidade" com relação à eleição passada, quando os separadores de resíduos colocaram uma chapa para concorrer com a atual. Sobre este aspecto de vista, não fica evidente se a questão da "vaidade", no sentido de poder, inicia-se pela associação de bairros ou pelos próprios separadores, pois mais adiante o entrevistado fala o seguinte:

Mas, nem queremos também muito, eles fazem o deles e a gente o nosso, mas eu acho que se fosse mais unido o trabalho, acho que seria melhor, ajudaria bem mais. (Entrevistado $n^{0} .6$ )

Mesmo se contradizendo no final desta frase, fica claro o descontentamento com a associação de bairro.

Já para o entrevistado $n^{\circ} .4$, acrescenta algo a mais: 
Ah eles (igreja) não fazem, mas para que fazer reunião, falar a toa para eles, é a mesma coisa que falar com a parede, fala ah ta concordo contigo! Quando tu viras a costa estão largando lixo no meio da rua, não adiante nada o pessoal não coopera uns com outros. Eles não estão esquentando.

Evidencia-se certa insatisfação deste associado com relação aos constituintes da igreja local, com a qual não existe um diálogo efetivo que possa mobilizar mudanças com relação à questão dos resíduos. Porém, seria necessário observar se esta comunicação foi realizada de uma forma que ficasse evidente a importância da reciclagem, e neste sentido, os sujeitos sociais também deveriam ter certo conhecimento sobre as questões ambientais, principalmente no que tange às problemáticas locais e, em específico neste estudo, os resíduos sólidos.

Nestes depoimentos, observou-se que a constituição da racionalidade instrumental expressa, como meio de tentar alcançar o propósito de mobilizar os sujeitos sociais para promover as mudanças ambientais naquela comunidade, não conseguiu contemplar uma participação maior por parte da comunidade local, pois a estratégia utilizada por estes trabalhadores, no caso o diálogo, não fora suficiente.

Contudo, não todos os sujeitos que não realizam reuniões, pois como se pode observar a seguir, verifica-se que os três entrevistados responderam que realizam ou realizaram algum tipo de encontro.

É, assim, a gente junta vamos supor assim, vai juntando, vai guardando! Então colocamos em uma caixa grande os calçados, e ai a gente faz uma reunião e vê assim ó, fulano lá está precisando. Ai vai, pega o pessoal da associação, vai lá e leva naquela casa. Geralmente quando se faz é no fim do mês. É que às vezes o próprio pessoal da associação vê os mais carentes e vai e leva na casa, porque assim, às vezes não adianta tu fazer uma reunião, aparecem 500 pessoas, aí duas precisam e o resto não precisa então a própria associação já sabe quem precisa. Ele vai vê a, casinha ali ta mais ou menos, tem alguém que necessita realmente, então ele vai lá e doa para aquela pessoa, que se tu fizeres uma reunião e chamar, tem muita gente que não precisa. (Entrevistado $n^{\circ} .2$ )

É a gente às vezes se reúne para ver o que vender e depois para nós vermos o que tem que fazer. (Entrevistado $\mathrm{n}^{\circ} .7$ )

Fizemos, uma vez por mês fizemos. (Entrevistado nº ${ }^{\circ}$ )

Leff (2001) relata que para se colocar em ação uma estratégia ambiental de desenvolvimento, aqui entendida como um envolvimento maior por parte das pessoas daquela comunidade, implica a ativação de práticas sociais alternativas.

Diante dessas respostas, percebe-se que os objetivos destas reuniões são variados, pois como respondeu o entrevistado $n^{\circ} .2$, sua participação nas reuniões 
seria para doar sapatos para aquelas pessoas mais necessitadas, e que as mesmas seriam realizadas uma vez por mês, porém o separador ressalta que, às vezes, não adianta realizá-las, pois podem aparecer "500" pessoas, mas destas, apenas duas são realmente necessitadas, e que isto seria decidido pela própria associação dos separadores de resíduos. Neste primeiro momento, evidencia-se que estas reuniões seriam apenas para doar acessórios, não aparecendo de forma objetiva à questão da importância da reciclagem como uma fonte de possibilidade para o processo de conscientização.

Para o entrevistado $n^{\circ} .7$, as reuniões seriam mais voltadas para atender as necessidades da venda dos seus materiais reciclados, e depois para discutirem o que teriam de fazer. Contudo, não descaracterizando a questão do lucro, deve-se lembrar que uma associação tem por finalidade a promoção de assistência social, educacional, cultural, representação política, defesa de interesses de classe, ou seja, não é formada para ter como objetivo central, fins lucrativos.

Um aspecto importante percebido nesta associação de separadores de resíduos seria a congruência entre os objetivos explícitos que levam à organização da mesma, e a eficácia de suas práticas concretas de ação e mobilização, gerando novas formas de participação, estratégias de mudança social.

Para tanto, estas reuniões teriam um caráter mais informativo com relação às questões dos resíduos recicláveis, caso abrangessem um maior número possível de pessoas ligadas àquela comunidade. Segundo os entrevistados, as assembléias são compostas por:

Têm alguns de fora também que vem participar. (Entrevistado $n^{\circ} .5$ )

Entre nós. Às vezes a gente reúne outras pessoas, não é muito seguido. (Entrevistado $\mathrm{n}^{\circ} .7$ )

Evidencia-se que a participação da comunidade não é muito significativa, pois são poucas que vêm a integrar estas assembléias. Em geral, uma efetiva participação da população implica num conhecimento das condições sociais e ambientais, análise e tomada de decisão em programas ou projetos que causam impactos no entorno e de forma permanente. Desta constatação, como há pouca participação da comunidade, fica mais difícil de conseguir envolver outros sujeitos sociais engajados em proporcionar uma qualidade ambiental melhor para eles. 
Entretanto, esta possibilidade de abranger mais pessoas da localidade parece ficar cada vez mais distante, pois como se pode verificar na seguinte fala:

Não, é assim, reunião assim não, porque, como eu te disse, vai juntar muita gente que não precisa a própria associação sabe quem precisa. (Entrevistado $\left.\mathrm{n}^{\circ} .2\right)$

Neste aspecto, deixa-se de envolver muitas outras pessoas que poderiam ser possíveis sujeitos para atuarem como responsáveis pela meio ambiente ao qual pertence, pois pelo que se evidencia pelas falas do entrevistado $n^{\circ} .2$, seria: "junta muita gente que não precisa", mesmo que este "precisa", como ele se referiu nas falas anteriores, está associado à distribuição de calçados. Contudo ele não observa a oportunidade que ocorre, pois no simples ato de doar os sapatos poderia estar associando esta ação com o trabalho por eles realizado na separação dos resíduos, divulgando, desta maneira, seu trabalho perante aquela comunidade, bem como do benefício que estão realizando para o meio ambiente.

Conforme Leff (2001), o saber ambiental se constitui através de processos políticos, culturais e sociais, que obstaculizam ou promovem a realização de suas potencialidades para transformar as relações sociedade-natureza. E mais, é um processo teórico que ocorre através de movimentos sociais, movimentos esses que podem ser alcançados pelo diálogo entre os associados e comunidade local.

Esta não realização da difusão das questões relacionadas ao meio ambiente pode ser compreendida quando perguntei a este mesmo entrevistado, falou sobre a importância da reciclagem:

Isso agora não está saindo porque, não tem assim um incentivo, toda a
reciclagem tem um incentivo, a única que não tem é essa. Agora tu me
dizes uma coisa, com 11 pessoas trabalhando, tu não ganhar um incentivo,
que seja lá 2.000 , que seja 3.000 , mas é um incentivo que tu podes ajudar,
pode pagar o INPS dessas pessoas sem precisa tu estares catando lixo!
Não tem um incentivo, não tem, e é lei, a lei ampara à gente de ganhar esse
incentivo, a gente não, a associação, de ganhar esse incentivo. Há quanto
tempo à gente já vem brigando por esse incentivo? Mais de 2 anos e eles
alegam (secretária do meio ambiente) que não tem. (Entrevistado $n^{\circ} .2$ )

Aqui fica claro que pelo fato da associação dele não ter nenhum incentivo por parte da secretária do meio ambiente, ocorre certa insatisfação em realizar reuniões voltadas para a orientação e conscientização da importância da reciclagem com a comunidade local. Ele alega que a única que não ganha incentivo algum seria a deles, mas isto não é de total acordo, pois conforme as falas a seguir: 
Luz e água é a prefeitura que paga, mas é o mínimo, não chega nem a da 100,00 reais por mês de luz e água, acredito. Fora isso ai não temos apoio nenhum. (Entrevistado $n^{\circ} .2$ )

Só deram o galpão aqui. (Entrevistado $\left.n^{\circ} .1\right)$

Já para o entrevistado $n^{\circ} .6$, quem fala alguma "coisa" sobre reciclagem são eles, sendo que estes encontros não são realizados seguidamente, e ainda, os envolvidos são apenas os membros da associação.

Não, quem fala alguma coisa sobre o negocio de reciclagem é nós mesmo, nós da associação, e também não é sempre, mas de vez em quando a gente conversa sobre alguma coisa. Vamos lá à reciclagem, conversamos lá. Não, a comunidade não participa. (Entrevistado nº. 6)

Leff (2001) ressalta que, como conseqüência dos conflitos socioambientais provocados pela racionalidade econômica ${ }^{15}$ dominante e pela centralização do poder, novos sujeitos têm vindo à cena política, fazendo novas reivindicações de melhoria da qualidade do ambiente e da qualidade de vida. Neste aspecto, quanto aos meios, caminhos utilizados para conseguir mobilizar a comunidade a visualizar a importância desta associação, os entrevistados falaram:

É de divulgação para reciclagem, mais nada, é, tem que ser uma divulgação, a gente faz, os colégios vem aqui, eu dou folhetos para eles, explico. Aí a professora passa mais adiante. Mas só uma divulgando não adianta! O ideal pra melhorar a divulgação é um veículo de comunicação, folhetos, fazer cartilha, fazer e distribuir nas escolas, se não fizer isso não adianta nada. Que um, dois trabalham certinho e $90 \%$ não trabalha, e isso ai é em longo prazo, não é do dia para noite que tu vai arrumar. (Entrevistado $n^{\circ} .1$ )

Nesta fala se observa que um dos caminhos esperados, seria de uma maior divulgação, pois como refere o entrevistado $n^{0}$. 1 , não apenas uma divulgação por parte dos associados, mas sim uma divulgação na forma de panfletagem, para distribuição nas escolas. Assim como ele diz, acredita-se que estes folhetos explicativos ajudem a divulgar a importância da reciclagem. No entanto, surge uma outra questão de suma importância, qual seja: que tipo de papel seriam confeccionados estes folhetos, pois utilizando o papel reciclado, abriria uma oportunidade de ressaltar o quanto à reciclagem pode transformar o que aparentemente estava descartado, sem valor de uso, podendo apresentar-se

15 Considerada aquela fundada na exploração da natureza e do trabalhador, por seu caráter concentrador do poder que segrega a sociedade, aliena o indivíduo e subordina os valores humanos ao interesse econômico. 
novamente com alguma utilidade. Dessa maneira, estar-se-ia ampliando o olhar dos moradores locais para a relevância da reciclagem, contribuindo para surgir novos sujeitos disseminadores de informações.

\begin{abstract}
Eu acharia que ele tinha que fazer mais propaganda sobre isso, eu acho que o meio ambiente (secretaria) tinha que fazer mais propaganda sobre isso, eles tinham que meter o corpo na frente. Nós temos secretaria do meio ambiente, nós temos secretário, supervisor, temo tudo, para quê? Só para ganhar e para escreve no papel. Eu nunca vi um secretário vim aqui, do meio ambiente. Precisa de uma propaganda mais divulgada, ou um caminhão com megafone, cobrando lixo reciclado, pedindo para as pessoas entregarem o lixo reciclado, deixarem o lixo reciclado naquela hora, naquele dia que o caminhão passar. O pessoal vai ver o caminhão passando com o megafone falando, e as pessoas vão dizer: "Está passando o caminhão do lixo reciclado, vamos levar." É essa divulgação para as pessoas reciclarem este lixo. (Entrevistado $n^{\circ} .2$ )
\end{abstract}

Como se observa nas falas do entrevistado $\mathrm{n}^{\circ}$. 2, quem estaria mais indicado a realizar esta parceria de disseminação da propaganda seria a secretária do meio ambiente, sendo que uma das maneiras seria há existência de um caminhão com alto falantes para lembrar as pessoas a entregarem seus resíduos recicláveis. Contudo, percebe-se que agindo desta maneira não seria o mais adequado, pois introduzir um caminhão na comunidade pedindo recicláveis, sem antes haver um diálogo, uma comunicação efetiva com os moradores locais, a qual abriria oportunidade de debater sobre o porquê daquela ação, as vantagens disto para aquela comunidade.

Para isto, uma maneira de abordar estas questões efetivamente com os habitantes daquele local seria a realização de palestras, oficinas, enfim, demonstrar o quanto às questões dos resíduos estão relacionados no seu dia-a-dia, e desta forma, realizar uma interação efetiva, proporcionando o engajamento de mais sujeitos.

Contudo, um aspecto importante que se apresenta na fala a seguir é de extrema relevância:

Eu acho que a secretaria do meio ambiente deveria fazer palestras. Seria o mais indicado partir da secretaria do meio ambiente, porque a gente fala, mas a gente não tem o conhecimento da causa. Isso que eu falei é a mais pura verdade, eles não dão, eu já disse, eles não dão apoio nenhum e nem vem, porque eles deveriam vir falar, deveriam vir olhar e te dar uma palestra para tu aprender. (Entrevistado $\mathrm{n}^{\circ} .6$ )

Não se deve difundir algo sem ter algum domínio de conhecimento daquele assunto. Pelas falas, percebe-se que eles "não têm o conhecimento de causa", ou 
seja, torna-se mais difícil querer englobar mais pessoas nesta ação, já que o conhecimento acerca desta é muito limitado. Nesse sentido, o entrevistado ressalta outro aspecto relevante, qual seja: o de buscar apoio na secretária do meio ambiente, a qual teria a princípio, um conhecimento maior para difundir, com os associados, as questões sobre reciclagem. Contudo, o mesmo diz que a secretária do meio ambiente não participa e nem dispensa algum tipo de apoio a eles. Ele acrescenta ainda:

Eu acho que deveria vir o secretario do meio ambiente fazer uma palestra, ou algum encarregado da secretaria a vir fazer umas palestras, para pode conscientizar as pessoas. (Entrevistado $n^{\circ} .6$ )

Para que ocorra efetivamente uma reunião com os associados e com a secretaria do meio ambiente, é necessário que exista um diálogo entre as partes envolvidas para que se possa discutir sobre a reciclagem, esclarecer dúvidas, trocar idéias, enfim, obter um canal que venha a servir de contato, de divulgação do trabalho realizado com os separadores de resíduos. Contudo, não foi identificado nenhum tipo de comunicação por parte dos associados com a secretaria do meio ambiente ou da secretária para a realização destas reuniões.

\subsubsection{Processo pedagógico ambiental}

O que se observou diante dos depoimentos obtidos pelos separadores de resíduos foi de que mesmo sendo difícil de conseguirem apoio, seja este da própria comunidade ou da secretária do meio ambiente, pôde-se identificar a possibilidade que alguns destes separadores apresentam em concretizarem o processo que Leff chama de pedagógico ambiental. Conforme o autor, esta pedagogia do ambiente surge da necessidade de orientar a educação dentro do contexto social e na realidade ecológica e cultural onde se situam os sujeitos do processo educativo (LEFF, 2001).

Pelas falas a seguir, pode-se evidenciar que surgiram muitas formas de tentar orientar e informar a comunidade local para a importância da reciclagem. Dentro dessas, algumas de uma forma muito momentânea, já outras de uma forma que tem como tendência se perpetuar por mais de uma geração, modificando, desta 
maneira, o modo de agir e pensar de uma comunidade, com relação à reciclagem e o meio ambiente.

A problemática ambiental, como sintoma da crise de civilização da modernidade, aqui se faz referência sobre a questão dos resíduos que não são reaproveitados, coloca a necessidade de criar uma consciência a respeito de suas causas e suas vias de resolução. Isto passa por um processo educativo que vai desde a formulação de novas cosmovisões e imaginários coletivos, até a formação de novas capacidades técnicas e profissionais. (Leff, 2001). Neste sentido, o entrevistado a seguir demonstra indícios para executar este processo educativo ambiental através de um diálogo com as escolas do próprio bairro.

É eles agendam e vem dar uma olhada na reciclagem. Podemos ir lá? Podem então elas vem aqui, cada um que vem aqui eu dou um folheto, elas chegam lá e tiram xérox. $90 \%$ dos alunos não sabem a quantidade de papel que precisa para não arrancar árvores, qual é o gasto de tu reciclares 1000 $\mathrm{kg}$ de papel para cortar árvore. E poucos sabem disso aí, poucos. (Entrevistado $n^{\circ} .1$ )

Ele possibilita divulgar para estas crianças, através da conversa e principalmente de um folheto explicativo, o quanto a atividade de reciclagem exercida pelos associados ajuda a contribuir para a questão do desmatamento. Esta atitude propicia para as crianças a oportunidade de conhecer um pouco mais da importância de estar reciclando continuamente, reorienta os valores que guiam o comportamento humano com a natureza, e mais, pode fazer surgir novos sujeitos comprometidos com esta problemática ambiental, que não se limita apenas ao entorno da comunidade.

Conforme Leff (2001), a pedagogia ambiental deve produzir e difundir os novos saberes e conhecimentos que permitirão a construção de uma nova organização social que respeite a natureza. Podem-se observar indícios desta pedagogia quando o mesmo entrevistado relata o seguinte:

É geralmente as crianças começa a falar um com outro o quanto custa para reciclar $1.000 \mathrm{~kg}$ de papel, o quanto demora para desmanchar um plástico, o alumínio. Tem retorno. Em seguida vem aqui a do Joanzinho (escola), vem a da COHAB 4. (Entrevistado $n^{\circ}$. 1)

Surge desta iniciativa uma divulgação de saberes que pode ser disseminada a muitas outras pessoas, transpassando os muros daquele bairro, englobando um maior número de sujeitos. Dentro deste processo, existe uma possibilidade para a 
existência da pedagogia ambiental, que imbricada na mesma encontra-se a educação ambiental, a qual deve orientar-se para a comunidade, procurando incentivar o indivíduo a participar ativamente da resolução dos problemas no seu contexto de realidades específicas, e a questão dos resíduos se faz presente continuamente no convívio daquela localidade (REIGOTA, 2002).

Outra maneira de se tentar realizar a pedagogia ambiental, a qual se julga muito rica no sentido da divulgação, assimilação e conscientização desta problemática ambiental para novos sujeitos, foi à iniciativa que teve o entrevistado a seguir:

Vêm às vezes livros, revistas, mas a minha parte é, já que eu gosto de dar aula, porque eu gosto desse lado da $1^{a}$ a $8^{a}$ serie assim, como reforço escolar, então às vezes vem livros didáticos que as pessoas colocam fora, uns livros bons à gente separa. (Entrevistado $n^{\circ} .6$ )

Esta atitude é muito produtiva pelo fato que estará contribuindo para qualificar os escolares daquela comunidade, contribuindo para ampliar seus conhecimentos, tornando esta prática em uma possível atitude pedagógica ambiental, pois os livros didáticos, as revistas disponibilizadas a estes estudantes são oriundas da própria reciclagem. Torna-se uma oportunidade de conscientizar os alunos da importância da reciclagem, do quanto ela beneficia, não somente o meio ambiente, mas também o meio educacional proporcionando acesso ao conhecimento além do âmbito escolar. Leff (2001) relata que a educação ambiental traz consigo uma nova pedagogia que surge da necessidade de orientar a educação dentro do contexto social e na realidade ecológica e cultural onde se situam os sujeitos do processo educativo, ou seja, implica na formação de consciências, saberes e responsabilidades que vão sendo moldados a partir da experiência concreta com o meio físico e social, para então buscar soluções aos problemas ambientais locais.

Neste sentido, a reciclagem possibilita meios de englobar mais sujeitos que possam se envolver com as questões socioambientais locais, favorecendo o entendimento deste a respeito do ambiente que os cerca.

Porém, o mesmo entrevistado ressalta a seguir que existe o interesse em querer difundir esta idéia para mais pessoas, através da construção de uma biblioteca. 
A gente tinha vontade de montar uma biblioteca, mas a gente não tem o lugar para montar uma biblioteca. A gente vai ver se faz uma sala para dar um reforço escolar para quem precisa. Então a gente já aproveita os livros e da uns livros, da para a gente tirar alguma coisa, para um trabalho, para alguma coisa, uma pesquisa que as crianças precisam. (Entrevistado $\mathrm{n}^{\circ} .6$ )

O que se pode constatar na fala do entrevistado $n^{\circ} .6$, é que a associação possui interesse em querer realizar este projeto, contudo ainda lhes falta um ambiente físico, uma sala onde possa ser montada a biblioteca. Um dos caminhos para que possa concretizar este projeto seria a inclusão da sociedade, a qual deve ser realizada através de diálogo, de palestras, de reuniões, conscientizando a importância deste outro projeto para a comunidade. Contudo, como observado no decorrer de algumas entrevistas, existem alguns empecilhos que podem dificultar esta união. Um deles é do fato de que as assembléias realizadas pelos associados, quando realizadas, não abrangem muitas pessoas além dos próprios associados. Além do mais, as reuniões não estão voltadas a debater questões que envolvam a importância de se realizar a reciclagem. Por fim, percebe-se que possíveis parcerias poderiam ser realizadas, como a associação do bairro, no entanto não acontecem. Desta maneira, torna-se uma tarefa muito árdua conseguir envolver outras pessoas engajadas e conscientes com tais idéias.

\subsection{RELAÇÕES ENTRE TRABALHO E SAÚDE}

Nesta categoria, transcrevem-se os depoimentos que se referem à percepção dos trabalhadores da associação entre 0 trabalho que esses desenvolvem e a saúde.

\subsubsection{O uso de Equipamentos de Proteção}

Com a aceleração dos processos de industrialização, urbanização e crescimento demográfico ocorreram aumento tanto em quantidade como em diversidade da produção dos resíduos sólidos, os quais passaram a abrigar, em sua composição, elementos sintéticos e perigosos à saúde, em virtude das novas tecnologias incorporadas à vida cotidiana. Conseqüentemente, a gestão e a 
destinação final do lixo passaram a exigir mais tratamento e meios adequados para a sua eliminação ou transformação física (RIGOTTO, 2002).

A constituição dos resíduos sólidos é diversificada e perigosa, em função do consumo desenfreado da sociedade capitalista e do aperfeiçoamento tecnológico. Rouquayrol (2003) ressalta que o lixo representa um elemento que não deve ser desprezado no estudo da estrutura epidemiológica, uma vez que, pela sua variada composição, poderá conter agentes biológicos patogênicos ou resíduos químicos tóxicos que poderão alcançar o ser humano direta ou indiretamente, afetando-lhe a saúde.

O manuseio dos resíduos, principalmente pelos separadores, exige o conhecimento dos riscos de doenças, contaminação e dos equipamentos de proteção individual (EPIs). Conforme a NR 06 (norma regulamentadora) do Ministério do trabalho, EPI é todo e qualquer dispositivo ou produto de uso individual utilizado pelo trabalhador, destinado à proteção de riscos suscetíveis de ameaçar a segurança e a saúde no trabalho. Entre os EPIs, para quem manuseia os resíduos, destacam-se as máscaras faciais de tecido, óculos de segurança, aventais de plástico, botas e luvas de couro (CAVALCANTE e FRANCO, 2007).

Com relação a essa particularidade do uso dos EPIs como instrumento protetor da saúde do trabalhador, foi perguntado aos entrevistados qual ou quais EPI (s) eles utilizavam no desenvolver de seu trabalho. Todos os oito trabalhadores referiram às luvas. Desses entrevistados, três relataram utilizar outro equipamento, dois o uso de máscara, e um o uso de sapatos.

Contudo, pelas observações no momento da realização das entrevistas, apenas um separador fazia o uso das luvas, o entrevistado $\mathrm{n}^{\circ}$. 3 , sendo que este mesmo as colocou após já estar realizando a separação dos resíduos. Esse fato pode ser sido influenciado pela presença do pesquisador no campo. Como se destaca nos exemplos de falas elucidadas a seguir:

Eu uso luva para não ter perigo de se cortar porque vem tudo misturado. . (Entrevistado $\left.\mathrm{n}^{\circ} .8\right)$

Olha a gente aqui usa luva, que a gente compra do bolso da gente, certo! Máscara, que a gente compra, agora mesmo terminou as máscaras, estão trabalhando sem, não estão usando máscara. (Entrevistado $n^{\circ} .2$ )

Ah, a gente usa luva. Ah, só luva, às vezes, quando tem muito lixo, muito pesado, que é muita garrafa, a gente tem que entra de, de tênis ou sapato, ah, se não agente se corta no meio. (Entrevistado $n^{\circ} .4$ ) 
Com relação ao uso das máscaras, nenhum separador relatou o uso, isso pode ser evidenciado na fala do entrevistado $n^{\circ}$. 2, apresentada anteriormente, ao mencionar o não uso das mesmas por não estar disponível no momento. Salientou ainda que a aquisição de novas máscaras dependa exclusivamente da compra pelos associados. O entrevistado $n^{\circ} .4$ acrescenta que eles utilizam tênis ou sapatos quando no material de reciclagem contêm garrafas de vidro. Entretanto, as observações permitem afirmar que todos os separadores faziam uso de chinelos de dedos, bermudas, e alguns se encontravam sem camisas. Esta realidade confirma uma condição de risco à saúde desses trabalhadores.

Somente um dos entrevistados associou do uso dos EPIs como conduta obrigatória em seu trabalho. Essa associação foi apresentada em sentido de punição e não como um direito do trabalhador à proteção de sua saúde.

Hoje que eles estão sem usar, mas o pessoal já coloca o EPI, o
equipamento obrigatório porque aqui é lei! Tem que usar a luva, a máscara,
tem que se proteger. Aquele que não obedece, ele é praticamente, a gente
faz uma reunião, e ele sai da associação, porque, ou ele entra nas normas
de risco ou ele sai fora. Não vamos prejudicar a saúde de uma pessoa
porque ele simplesmente não quer utilizar uma luva! Tem que obedecer
aquilo que foi criado dentro da associação. (Entrevistado $n^{\circ}$. 2)

Mesmo sendo obrigatória a utilização dos EPIs, segundo o entrevistado $\mathrm{n}^{\circ}$. 2, isto foi acordado dentro daquela associação. No entanto, não se visualizou, salvo o entrevistado $n^{\circ}$. 3, nos demais recicladores o emprego dos equipamentos de proteção. Um dos motivos de não possuírem todos os EPIs, segundo o entrevistado $\mathrm{n}^{\circ}$. 2, está ao não fornecimento destes equipamentos por parte da prefeitura municipal, quando o entrevistado relata que é obrigação da prefeitura em fornecer este material.

A gente paga aquelas máscaras do bolso da gente porque eles não nos dão um equipamento obrigatório. A prefeitura que era para dar, não nos dá um equipamento obrigatório, e nem o meio ambiente (secretaria) nos dão. $O$ EPI eles não dão, não dão uma bota, eles não nos dão um avental. (Entrevistado $n^{\circ} .2$ )

Inclusive até essa prensa não é da associação, é só minha, eu tinha ela lá (no lixão) e, fecharam lá e viemos para cá. A única reciclagem da cidade que eles não deram nada foi essa aqui. As outras todas receberam equipamentos, tudo. Só deram o galpão aqui. (Entrevistado $n^{\circ} .1$ ) 
O entrevistado $n^{\circ}$. 1 acrescenta que a associação (ASTARR) deles foi à única, dentre todas do município, a não receber nenhum equipamento. Segundo o entrevistado $\mathrm{n}^{\circ}$. 2, acaba sendo os próprios associados que pagam pelos equipamentos de proteção individuais.

Ao manusearem os resíduos, à procura de materiais que possam ser comercializados, os catadores estão expostos a todos os tipos de riscos de contaminação presentes nos resíduos.

A não utilização destes EPIs pode acarretar em muitos danos para a saúde destes trabalhadores. De acordo com Cavalcante e Franco (2007), a exposição da saúde humana e ambiental aos agentes danosos a partir dos resíduos ocorre de duas formas: pelo modo direto, quando há um contato estreito do organismo humano com agentes patogênicos presentes no resíduo, e pelo modo indireto, por meio da amplificação de algum fator de risco, que age de forma descontrolada sobre o entorno e por três vias principais, a saber: a ocupacional, a ambiental e a alimentar.

A via ocupacional particulariza-se pela contaminação dos catadores, os quais manipulam substâncias consideradas perigosas sem nenhuma proteção. Neste estudo em especial, evidenciou-se o não uso dos EPIs. Embora atinja uma parcela reduzida da população, esta via manifesta a forma mais agressiva de contaminação (GONÇALVES, 2005).

\subsubsection{Riscos e Perigos no desenvolver de seu Trabalho}

Nesse sentido, foi questionado aos participantes do referido estudo, como eles descreveriam os riscos e perigos para a sua saúde ao desenvolver o seu trabalho.

Segundo Porto (2000), o risco pode ser entendido como toda e qualquer probabilidade de que algum elemento ou circunstância existente num dado processo e ambiente de trabalho possa causar dano à saúde, seja através de acidentes, doenças ou do sofrimento dos trabalhadores, ou ainda através da poluição ambiental. Já o perigo é uma situação com o potencial de criar danos, 
designadamente ferimentos ou lesões pessoais, mas pode, também, causar danos para a propriedade, instalações, equipamentos, ambiente ou perdas econômicas.

\begin{abstract}
É isso aí, muitos colocam seringas descartáveis, agulha, equipamento de soro, que usam, vem tudo. O que vem muito são essas seringas pequenas de insulina, isso vem bastante. Tem que se cuidar para não espetar. É, mas tem! (Entrevistado $\left.n^{\circ} .1\right)$

Injeção eles mandam, coisas de hospital, veneno, vidro quebrado. (Entrevistado $n^{\circ} .3$ )

O único perigo é de se cortar, de introduzir um aparelho de injeção que tu nem sabe de quem é que vem com uma agulha, isso ai a pessoa tem que se cuidar para não se machucar. Ah vem agulha, vem vidro quebrado, isso ai a pessoa tem que se orientar porque se não acaba se cortando e nem sabe de onde vieram os vidros. Às vezes vem vidro de hospital. (Entrevistado $\left.\mathrm{n}^{\circ} .4\right)$
\end{abstract}

Para estes entrevistados, o perigo máximo que eles atribuem ao seu trabalho está relacionado a materiais perfurocortantes, como as agulhas e os vidros, como um risco de solução de continuidade no corpo (corte; picada entre outros). Salienta-se que esses não relacionam a possibilidade de contaminação de um agente biológico por meio dessa via de transmissão. Para Ferreira e Anjos (2001), estes agentes, considerados como físicos, são capazes de interferir na saúde humana e no meio ambiente.

Os agentes biológicos presentes nos resíduos sólidos podem ser responsáveis pela transmissão direta e indireta de doenças. Microorganismos patogênicos ocorrem nos resíduos sólidos mediante a presença de lenços de papel, curativos, fraldas descartáveis, papel higiênico, absorventes, agulhas e seringas descartáveis e camisinhas, originários da população; dos resíduos de pequenas clínicas, farmácias e laboratórios e, na maioria dos casos, dos resíduos hospitalares, misturados aos resíduos domiciliares (FERREIRA, 2004).

Alguns agentes que podem ser ressaltados são os vírus causadores das hepatites, principalmente do tipo $B$, pela capacidade de resistirem em meio adverso, e o vírus causador da Síndrome da Imunodeficiência Adquirida (AIDS), mais pela comoção social que desperta do que pelo risco associado aos resíduos, já que apresenta baixíssima resistência em condições adversas (FERREIRA e ANJOS, 2001).

Outro tipo de perigo à saúde, abordado por um entrevistado, foi à presença de lâmpadas fluorescentes nos resíduos. 
Claro que sempre existe um risco de contaminação, por mínimo que ele seja, sempre tem, é complicado. O material que vem ele é um material que não é sujo, mas ele é semi-sujo. Até agora nós temos um problema grande que é da lâmpada florescente, que é uma contaminação direta com chumbo, mercúrio, isso é um dos maiores perigos que o nosso meio ambiente [o entrevistado está se referindo à Secretaria do Meio Ambiente do município do Rio Grande] não ta enxergando isso, a gente não tem um depósito apropriado para isso. A gente coloca em latões. (Entrevistado $\mathrm{n}^{\circ}$. 2)

Segundo Ferreira e Anjos (2001), metais pesados como chumbo, cádmio e mercúrio, incorporam-se à cadeia biológica e possuem efeito cumulativo, podendo provocar diversas efeitos deletérios à saúde humana e ao meio ambiente. No ser humano, podem surgir doenças como saturnismo ${ }^{16}$ e distúrbios no sistema nervoso, entre outras.

O entrevistado ressalta que o responsável pela disposição final deste material em particular seria a secretaria do meio ambiente, mas que no momento não está oferecendo o suporte adequado para a associação. Segundo o decreto $N^{\circ}$. 45.554, de 19 de março de 2008, que regulamenta a Lei $n^{\circ} 11.019 / 97$, de 23 de setembro de 1997 do Estado do Rio Grande do Sul, em seu Art. 1 - É vedado o descarte de pilhas que contenham mercúrio metálico, lâmpadas fluorescentes, baterias de telefone celular e demais artefatos que contenham metais pesados em lixo doméstico ou comercial. $\S 1^{\circ}$ - Estes produtos descartados devem ser separados e acondicionados em recipientes adequados para destinação específica, ficando proibida a disposição em depósitos públicos de resíduos sólidos e a sua incineração.

No que diz respeito à responsabilidade destes produtos, o mesmo decreto ressalta em seu Art. $5^{\circ}$, que os fabricantes e importadores destes produtos, são responsáveis pela adoção de mecanismos adequados de gestão ambiental e destinação final dos resíduos sólidos gerados no "pós-consumo", descartados pelos consumidores, devendo cadastrar-se na FEPAM $^{17}$. Como ressaltado, o acondicionamento destes agentes tóxicos se efetiva por meio de latões. Esse conhecimento pode ser visualizado pelo mesmo entrevistado $\mathrm{n}^{\circ}$. 2 ao acrescentar em seu depoimento:

\footnotetext{
${ }^{16}$ Doença causada pela intoxicação pelo chumbo.

${ }^{17}$ Fundação Estadual de Proteção Ambiental
} 
Não nos deram nenhum apoio, um reservatório para nós mantermos aquelas lâmpadas florescentes ali. Não tem quem venha reciclar essas lâmpadas florescentes. O que acontece é que a gente pega, coloca no lixo, para o caminhão do lixo levar para o lixão municipal, porque a gente não tem um depósito. É a mesma coisa que pilha e bateria, não tem quem venha busca esta pilha, essa bateria, o que a gente vai fazer com isso? (Entrevistado $\left.n^{\circ} .2\right)$

De acordo com o boletim da Gestão Ambiental (2003) o acondicionamento das lâmpadas fluorescentes deve ser em contêineres especialmente desenvolvidos para esse tipo de transporte, capaz de reter eventuais emanações de mercúrio. Deve-se também, evitar choques no carregamento, manuseio e transporte do contêiner, não sendo apropriado tombar o contêiner, mantendo-o sempre na posição normal. O mesmo decreto menciona em seu Art. $9^{\circ}$, $\S 1^{\circ}$ que a localização de instalações para o armazenamento intermediário de resíduos sólidos oriundos do "pós-consumo", deve ser licenciada junto a FEPAM.

Além desses perigos com os metais pesados, outro problema levantado pelo entrevistado a seguir diz respeito ao odor desagradável, oriundo dos materiais recicláveis.

Ah, algumas coisas tem cheiro ruim. (Entrevistado $n^{\circ} .7$ )

O odor emanado dos resíduos pode causar mal-estar, cefaléias e náuseas em trabalhadores e pessoas que se encontrem proximamente a equipamentos de coleta ou de sistemas de manuseio, transporte e destinação final. Um agente comum nas atividades com resíduos é a poeira, que pode ser responsável por desconforto e perda momentânea da visão, além de problemas respiratórios e pulmonares (FERREIRA e ANJOS, 2001). Os autores ainda acrescentam que nem sempre lembrada, a questão estética é bastante importante, uma vez que a visão desagradável dos resíduos pode causar desconforto e náusea.

Outro perigo relatado pelos entrevistados é a proliferação de ratos, pulgas e baratas no ambiente de trabalho.

Para rato aqui é uma briga, tu tem que implorar para eles virem aqui colocar remédio para rato, que isso aqui cria rato! Pulga também, que é um ambiente fechado muito quente. (Entrevistado $\mathrm{n}^{\circ} .8$ )

E seguida à gente está colocando um inseticida para matar pulga, barata, para não deixar criar. Semana passado mesmo andava aparecendo umas pulgas, colocamos bastante remédio, agora termino, agora tu podes caminhar. (Entrevistado $n^{\circ} .5$ ) 
Segundo Ferreira e Anjos (2001), a pulga pode transmitir doenças como, por exemplo, o tifo (febre tifóide), a solitária, a encefalite, a tularemia ${ }^{18}$ e até mesmo a peste bubônica, que em apenas seis anos dizimou um terço ou mais da população da Europa na Idade Média. A barata, que gosta da sujeira, também é suspeita de transmissão mecânica de doenças, como a asma. Já os ratos podem transmitir a leptospirose através da sua urina, que provoca a doença ao penetrar nas mucosas, através de ferimentos da pele ou da ingestão da água contaminada, além de transmitir a hantavirose, quando respiramos o ar de lugares contaminados com vírus encontrado nas fezes e urina de ratos do mato. Mordeduras ocasionadas por ratos e outros roedores são freqüentes, produzindo, às vezes, mutilações graves, normalmente entre crianças e indivíduos idosos.

Continuando os depoimentos dos entrevistados, surge outro aspecto interessante nas falas, que é a questão do perigo ser mínimo ou nulo no local de trabalho.

Eu acho que não, primeiro tu usa luva, você não faz nada sem lavar bem as mãos, principalmente quando vai fazer uma refeição, eu acho que não tem risco nenhum, em relação a isso eu acho que não. (Entrevistado $n^{\circ} .8$ )

Então o perigo para nós é mínimo, é mínimo porque a gente trabalha com bota, máscara e luva, a gente trabalha com este, este material de proteção. (Entrevistado $\left.n^{\circ} .2\right)$

Eu acho que não porque ali o que mais vai é lixo limpo, só quando tem algum vidro, mas os guris têm equipamento, os guris trabalham com equipamentos, eu acho que perigo não tem, é tudo separado, os guris separam tudo. (Entrevistado $\mathrm{n}^{\circ} .6$ )

Acho que não tem risco nenhum. Acho que não tem problema nenhum. (Entrevistado $\left.n^{\circ} .5\right)$

Os entrevistados abordam os perigos como mínimos, pois como relatam o entrevistado $\mathrm{n}^{\circ} .2$ e o $\mathrm{n}^{\circ}$. 6, eles estão sempre utilizando os EPIs, fato não averiguado durante o processo de entrevista. Para o entrevistado $\mathrm{n}^{\circ}$. 8, a questão do perigo está associada à lavagem das mãos antes de realizar alguma refeição. Ele menciona que realizando uma adequada higiene antes das refeições, os riscos são praticamente nulos. Porém, os entrevistados se contradizem, quando se referem à utilização das luvas, fato não evidenciado naquele momento.

Os riscos ambientais decorrentes da ação humana constituem um aspecto da complexa interação das pessoas com o meio ambiente. Nesse sentido, o

\footnotetext{
${ }^{18}$ é uma doença infecciosa rara que pode atacar a pele, olhos e pulmões.
} 
conhecimento desses riscos está diretamente associado às reações que envolvem a percepção dos indivíduos e as suas experiências e vinculações com seu espaço de vida (CAVALCANTE e FRANCO, 2007).

\subsubsection{Trabalho e ferimentos}

Segundo Ferreira e Anjos (2001), cortes com vidros caracterizam o acidente mais comum entre trabalhadores catadores de resíduos. As estatísticas deste tipo de acidente são subnotificadas, uma vez que os cortes de pequena gravidade não são, na maioria das vezes, informados pelos trabalhadores, pois não os consideram acidentes de trabalho. Isto pode ser observado no depoimento do entrevistado $n^{\circ}$. 1 , que não considera acidente de trabalho o seu corte, pois ressalta que corte todo mundo teve.

Não, graças a Deus. Só de cortar, um cortezinho todo mundo teve. É vidro, largam o vidro de qualquer jeito ali dentro, a gente vai pegar o saco, abre e se corta. (Entrevistado $n^{\circ} .1$ )

Pouca coisa assim, com um fardo. Só foi um arranhão. (Entrevistado $n^{\circ} .7$ )

Não, eu não! Já teve um funcionário que já se feriu, principalmente com caco de vidro. Às vezes vem vidro quebrado, vem alguma coisa, e as luvas, claro, protege, mas no caso de um caco de vidro ele sempre corta. E às vezes o próprio pessoal da reciclagem que vem, e começa a atirar as coisas. Aí soltou um caco de vidro e cortou até outra pessoa! Por causa de má prudência deles, mas foi só isso que aconteceu assim de inesperado. (Entrevistado $\mathrm{n}^{\circ} .2$ )

Com vidro, abri a mão. Aqui no dedo. Eles deixam os vidros quebrados na bolsa assim quando o cara vai pega. (Entrevistado $n^{\circ} .3$ )

A principal causa de acidentes com vidros é a falta de informação e conscientização da população em geral, a qual não se preocupa em isolar ou separar vidros quebrados dos resíduos apresentados à coleta domiciliar, como relata o entrevistado $n^{\circ}$. 3. A adoção obrigatória de sacos plásticos para o acondicionamento dos resíduos sólidos municipais, com efeitos positivos na qualidade dos serviços de limpeza urbana, infelizmente amplia os riscos pela opacidade dos mesmos e ausência de qualquer rigidez que possa proteger o trabalhador. A utilização de luvas pelo trabalhador atenua, mas não impede a maior 
parte dos acidentes, que não atingem apenas as mãos, mas também braços e pernas (FERREIRA e ANJOS, 2001).

Além dos resíduos não virem rotulados, principalmente quando existe perfurocortantes como o vidro, o entrevistado $\mathrm{n}^{\circ}$. 2 relata que o único acidente de trabalho que ele presenciou, derivou de uma falta de prudência por parte do pessoal encarregado de trazer os resíduos sólidos coletados no município.

Com relação a estes trabalhadores, que tiveram algum acidente de trabalho separando os resíduos sólidos recicláveis, questionou-se a quem eles recorreram após o ocorrido e quais procedimentos realizados.

Em um postinho, fizeram um curativo, fizemos os primeiros socorros aqui e a gente vai ali, tem que esperar bastante, mas fomos atendidos. Primeiro é a enfermeira para depois o médico dar a receita. Estavam tudo em dia as vacinas, mas só um curativo e bom, vá embora. Nada mais.

(Entrevistado $\left.n^{\circ} .1\right)$

Não, só botei álcool e deu. Não procurei o serviço de saúde. (Entrevistado $\left.n^{\circ} .3\right)$

Não, não precisou de atendimento de saúde, só foi descuido. (Entrevistado $\left.\mathrm{n}^{\circ} .7\right)$

O que se percebe nos depoimentos acima, é que apenas o entrevistado $\mathrm{n}^{0} 1$ procurou atendimento de saúde para avaliar seu ferimento. Relata que prestou os primeiros socorros no local de trabalho e após encaminhou-se para a unidade básica de saúde, onde foi atendido pela Enfermeira e após pelo médico, onde receitou medicamentos e realizou um curativo. Mencionou, também, que não necessitou realizar vacina, pois estava em dia com a mesma.

Já nos depoimentos dos entrevistados $n^{\circ} .3$ e o $n^{\circ}$. 7, os mesmos dizem não procuraram atendimento de saúde. Um dos riscos frente à exposição de acidentes com perfurocortantes, neste caso em particular com os vidros, é a ocorrência do tétano. Segundo Ministério da Saúde (2005), o tétano, uma das doenças infecciosas de maior letalidade, com elevada prevalência em nosso país. A infecção ocorre pela introdução dos esporos em solução de continuidade da pele ou mucosas (ferimentos superficiais ou profundos de qualquer natureza).

Além da vacinação de rotina, de acordo com os calendários de vacinação da criança, do adolescente, do adulto e do idoso, destacam-se, em particular, a identificação e vacinação de grupos de risco, como trabalhadores da construção civil e da agricultura, catadores de resíduos, trabalhadores de oficinas mecânicas, etc. 
(Ministério da Saúde, 2005). Portanto, uma avaliação clínica (anamnese ${ }^{19}$, exame físico, carteira de vacinação) está indicada em situações de acidentes de trabalho como os citados neste estudo em particular.

\subsubsection{Mudanças para melhorar a saúde no trabalho}

Nesta subcategoria, surgem depoimentos referentes há possíveis melhorias no local de trabalho que possa contribuir para melhorar a saúde destes separadores.

Que eles (a prefeitura) dessem mais assistência, essa da saúde porque, rato, aqui tem bastante. Controle de zoonose, porque aqui eles não vêm, à gente que tem que colocar veneno, volte e meia porque, rato aparece e fica! Aqui quando os vizinhos falam, a gente vai lá e compra lá, gasta aí 50, 100 pila de veneno e coloca. Eles não vêm para colocar. Que quando eles vêm tem que ter toca para eles colocar. Não adianta toca, eles têm que colocar ali por cima, por baixo, só na toca não adianta não. É para melhorar seria isso. (Entrevistado $\mathrm{n}^{\circ} .1$ )

Para o entrevistado, o que poderia mudar para melhorar a saúde do local de trabalho, seria o apoio da prefeitura no combate ao controle dos roedores. Ele menciona que a verba destinada ao veneno no combate aos ratos é desembolsada pela própria associação.

Segundo a Enciclopédia de Pragas Urbanas (2003), o acúmulo de resíduos beneficia a criação de ratos que encontra, principalmente no lixo doméstico, o seu alimento. Devido à associação de reciclagem trabalhar com papelão, papéis, isto acaba propiciando um habitat para estes roedores. Se não realizado um controle destes roedores, acabam se reproduzindo intensamente. As fêmeas podem ter até dez ninhadas por ano, com 5 ou 6 crias por ninhada, podendo ocasionalmente chegar a 12.

Olha, vou te dizer assim, para mudar a gente precisa de uma manutenção
melhor da prefeitura, um apoio melhor, a gente precisa de ampliar isso aqui,
fazer um galpão, fazer um depósito de lâmpada florescente, fazer um
depósito para baterias celular, para pilha. Isso são tipos de coisas que a
gente não tem, a gente coloca em latões, por que não tem, e não adiante a
gente fazer um latão, um depósito aberto, porque ai vai encher de água.
Aquela água vai correr e vai contaminar o solo por mercúrio, por radiação
da bateria, por radiação da pilha, que é o mais grave hoje no mundo. Então

${ }^{19}$ Segundo a enciclopédia wikipedia, é uma entrevista realizada por um profissional da área da saúde com um paciente, que tem a intenção de ser um ponto inicial no diagnóstico de uma doença. Em outras palavras, é uma entrevista que busca relembrar todos os fatos que se relacionam com a doença e à pessoa doente. 
é isso que a gente queria assim, um apoio melhor dos governos, da FURG, é do meio ambiente (secretaria) que não aparece nunca. Não é assim, estamos pedindo o máximo! Nós estamos pedindo o mínimo para a saúde, o mínimo para não contamina o nosso solo e as nossas pessoas. É essa a nossa preocupação. (Entrevistado $n^{\circ}$. 2)

Para o entrevistado $n^{\circ}$. 2, a questão da melhoria da saúde, também está relacionada com um apoio melhor por parte da prefeitura municipal. Ele entende que com uma possível ampliação do galpão da associação, poderia ser construído um depósito apropriado para armazenar as lâmpadas fluorescentes, baterias de celulares e pilhas. Como citado anteriormente, esses produtos podem provocar danos ambientais se acondicionados de forma errônea. Conforme Barandas (2000), todas as pilhas e baterias recarregáveis de $\mathrm{Ni}^{20}, \mathrm{Cd}^{21}$, de uso doméstico e geral, quase todas as baterias do tipo botão e as do tipo fixo, embutidas no equipamento, são consideradas perigosas do ponto de vista sanitário e ambiental. Quando descartados sem controle, junto com o resíduo sólido comum, podem se transformar em substâncias extremamente perigosas e tóxicas à saúde e ao ambiente, pela possibilidade de reação, interação ou sinergismo com outras substâncias presentes no resíduo sólido urbano, ou no ecossistema, devido a inúmeros fatores.

O entrevistado demonstra certa preocupação não só com sua saúde, mas também com a saúde da comunidade e do ambiente, pois conhecendo os possíveis problemas ambientais que estes produtos podem gerar para comunidade, visualiza na possibilidade de se construir um depósito apropriado, uma maneira de se evitar este dano.

Outro fator, apresentado pelos entrevistados $n^{\circ} .3$ e o $n^{\circ} .8$, no que tange ao aspecto da melhoria da saúde através do ambiente de trabalho, está relacionado à questão da separação dos resíduos antes de chegar até a eles.

\footnotetext{
Mudaria assim: que eles mandassem o lixo reciclado, que era só nós derramar e deu tudo separadinho. O pessoal não separa, vem tudo rasgado, o pessoal do caminhão rasga tudo, tem vidro, jogam, não obedece mais. (Entrevistado $n^{\circ} .3$ )

Bom seria o material que se viesse mais limpo. O material que vem para gente fazer a separação vem tudo misturado com absorvente. Nessas coisas vem vidro, eles não separam. Então a gente tem que separar, não vem limpo para separar, o material reciclável e não reciclável. Não ali vem tudo misturado. Se viesse assim separadinho seria bem melhor. (Entrevistado $\left.n^{\circ} .8\right)$
}

\footnotetext{
${ }^{20}$ Níquel.

${ }^{21}$ Cádmio.
} 
Segundo os depoimentos dos entrevistados $n^{\circ} .8$ e $n^{\circ} .3$, o que contribuiria para melhorar não somente a sua saúde, mas também o seu trabalho, seria que os resíduos que ali chegam, viesse já separado de acordo com sua classificação. Esta atitude pouparia tempo e diminuiria possíveis acidentes de trabalho. Para tanto, segundo Almeida (2000) isso pode ocorrer desde que se tenha uma coleta seletiva no município e que haja uma conscientização da população sobre a importância da separação seletiva dos resíduos sólidos. O autor acrescenta que este resíduo pode ser reincorporado no caso de um processo industrial, desde que seu descarte ocorra de maneira adequada e seletiva.

Continuando com os depoimentos, surgem dois entrevistados, os quais têm pensamentos distintos em relação ao que poderia ser realizado para melhorar o seu local de trabalho.

É eu acho que, para melhora, aqui não tem como tu melhora porque o seguinte, isso aqui é uma reciclagem, tu trabalha às vezes com produto limpo, às vezes vem sujo. A pessoa se cuida para não se machucar, para não pegar nada que nos chega muito contaminado, mas não da para fazer nada, é uma reciclagem! Uma que não é um serviço limpo. Se fosse um serviço limpo tu não precisava andar de macacão, de luva, de bota. (Entrevistado $n^{\circ} .4$ )

Ah, eu acho que está trabalhando adequado. O local nosso onde estamos trabalhando acho que está certo, não tem prejuízo nenhuma. (Entrevistado $\left.n^{0} .5\right)$

O entrevistado $n^{\circ} .4$ percebe que no ambiente que desempenha seu trabalho, não existe uma maneira de melhorá-lo em prol da saúde da associação, pois sua atividade é considerada como não "limpa", pois necessita de EPIs como macacão, luvas e botas para realizá-la. Relata ainda que sua atividade de separação desempenha-se não somente com resíduos limpos, mas inclusive com os sujos. Segundo Almeida (2000) resíduo limpo é tudo aquele que pode ser reaproveitado nos processos industriais, como vidros, papel, alumínio, garrafas plásticas, ferro, ou seja, o material reciclado. Já os resíduos sujos são todos os resíduos que contém restos orgânicos incorporados a eles.

Já para o entrevistado $n^{\circ} .5$, não teria nada a modificar, pois conforme ele o local de trabalho está sendo realizado de forma adequada, não oferecendo prejuízo algum para eles. Para Pinheiro (2003), os riscos ambientais decorrentes da ação humana constituem um aspecto da complexa interação das pessoas com o meio ambiente. Nesse sentido, o conhecimento desses riscos está diretamente associado 
às reações que envolvem a percepção dos indivíduos e as suas experiências e vinculações com seu espaço de vida.

\subsubsection{Mudanças para melhorar a saúde na comunidade.}

Além das mudanças necessárias no local de trabalho para melhorar a saúde, perguntou-se a estes separadores, o que eles percebiam na comunidade que poderia ser modificado para melhorar a sua saúde. A maioria dos entrevistados diz que manter os pátios das casas e de terrenos baldios sem o acúmulo de resíduos, já seria uma mudança significativa. Outros consideram importante modificar na comunidade o atendimento de saúde prestado na unidade básica de saúde. Esses depoimentos encontram-se a seguir.

Mudar a comunidade? Tem umas casas ai que tem lixo. Reciclar eles não reciclam. Estão acumulando o lixo. Valetas com doenças. Bah tem campos que tu olha, cheio de lixo. Jogam tudo ali. (Entrevistado $n^{\circ} .3$ )

Olha, se eu fosse um presidente de um bairro, teria muita coisa para faze nesta vila, que tem defeito. É pátio abandonado que o pessoal não vem morar e a prefeituras não se importam de limpar, cansemos de pedir para limpar uns pátios abandonados onde cria lixo, eles vem quando agrada. (Entrevistado $\left.n^{\circ} .4\right)$

Cada um ter, manter os pátios limpo, não atirando nada na rua, deixa garrafas, junte bote tudo separado no dia da coleta. Largue na rua o caminhão recolhe, não deixa atirado nos pátios ai, não acumula água, essa doença da dengue ai. Tudo ajuda. (Entrevistado $n^{\circ} .5$ )

Nisso ai, esse bairro ai é um lixo, tem pessoas, tem gente que depois que passa o lixeiro joga os lixos nos quintais vazio, nos quintais baldios, isso ai é uma mão cheia para a proliferação de ratos, baratas. Nessas valetas às vezes tem, apesar de que isso aqui em plástico voa, não adianta nada, mas os próprios lixeiros quando fazem à coleta eles não juntam tudo. Eles atiram e o que cair eles não coletam. (Entrevistado $n^{\circ} .6$ )

Eu acho que estas pessoas que jogam lixo no caso, têm um monte de pessoas que não respeita nada não, a gente tenta conversa com eles tudo lá, mas tem uns que não adianta. Ah, a gente faz eles não fazem. (Entrevistado $n^{\circ} .7$ )

Os resíduos acumulados a céu aberto podem gerar grandes problemas ao meio ambiente e à saúde, pois estes costumam atrair e proliferar vetores, como moscas, baratas, ratos, etc., que podem trazer muitas doenças. Os resíduos depositados em solos, sem nenhuma preparação anterior, proporcionam a 
penetração do chorume pela terra, levando substâncias contaminantes para o solo e para o lençol freático.

A constituição Federal, em seu $7^{\circ}$ artigo, da lei 2.089/96 prevê que é de responsabilidade das prefeituras o recolhimento e cuidado com os resíduos urbanos, proibindo que se jogue lixo ou entulho em lugares não adequados. Segundo a lei, estes atos podem ser caracterizados como crimes ambientais e contra a limpeza pública.

Bom, a saúde é: chega ao posto ali, não te atendem para consultar com um médico! Tens que agendar! Desde quando que a doença é agendada, e não te atendem, pode esperar lá, tu espera lá, vem enfermeira, enfermeira te tira a febre, te olha, vai lá, conversa com o médico, aí o médico prescreve, e aí ela te dá para você! Eu acho que não pode ser assim. A saúde ta péssima aqui para comunidade, péssima, péssima. (Entrevistado $\mathrm{n}^{\circ} .1$ )

Para mudar o negócio da saúde? Bom para o bairro seria um posto médico, doutores, médicos, que são mal atendidos. Para mim isso seria isso. (Entrevistado $\mathrm{n}^{\circ} .8$ )

$\mathrm{Na}$ compreensão destes entrevistados, a mudança na comunidade necessária para melhorar a sua saúde está associada à unidade básica de saúde daquela localidade. Dizem que o atendimento é de péssima qualidade e são mal atendidos.

Conforme o Ministério da Saúde (2002), a atenção básica representa o principal meio pelo qual a população em geral acessa o sistema de saúde, sendo composta por Unidades Básicas de Saúde, as quais são espaços alocados de maneira a cobrir todo o território de uma esfera política municipal. Prestar um atendimento de qualidade, integral e humano em unidades básicas municipais, garantindo o acesso à assistência e à prevenção em todo o sistema de saúde, de forma a satisfazer as necessidades de todos os cidadãos, deveria ser o objetivo principal dessas unidades. 


\section{CONSIDERAÇÕES FINAIS}

Pode-se considerar que os objetivos da pesquisa em questão foram alcançados, uma vez que foi possível levantar dados acerca da compreensão que os separadores de resíduos recicláveis têm do seu trabalho e deste relacionado com o ambiente e a saúde.

Neste sentido, algumas considerações foram relevantes neste estudo. Com relação à categoria da Racionalidade Cultural, a qual é entendida como um sistema de significações que produz a identidade e integralidade de cada cultura, dando coerência a suas práticas sociais e produtivas em relação às potencialidades de seu entorno geográfico e de seus recursos naturais, surgiram significações relacionadas entre o trabalho desenvolvido pelos separadores de resíduos e ao meio ambiente, a comunidade e a renda.

Na relação trabalho e Meio Ambiente, evidenciou-se algumas considerações relevantes a serem discutidas. Primeiramente, a significação que os separadores fazem com relação ao seu trabalho e o meio ambiente, sendo a mais relatada entre os depoimentos, visto que esteve associada à questão de limpeza e higiene, ou seja, como manter o bairro mais limpo. Isto demonstra o quanto, para estes trabalhadores, a poluição, principalmente no que se relaciona com os resíduos sólidos está diretamente associada ao espaço de vida. A questão de preservar as ruas, terrenos e pátios livres de resíduos depositados a céu aberto foram uma das preocupações mais constantes entre os entrevistados. Esta preocupação em relação à limpeza do ambiente esteve associada a outro significado, identificado no decorrer desta pesquisa, qual seja: a percepção, por parte de um destes sujeitos, como sendo uma pessoa que cuida do meio ambiente, através da atividade de reciclagem. Isso demonstrou que a atividade de reciclagem desperta sentimento, neste caso específico, o de zelar pelo ambiente, o qual vai além do espaço de trabalho.

Ainda apareceram outros sentidos entre a relação deste trabalho dos separadores e meio ambiente, como a questão de evitar o desmatamento, de preservação das plantas, da não contaminação dos solos e do surgimento de certas doenças, pois a disposição inadequada dos resíduos pode assolar a comunidade local. Isto pode estar de certa maneira, associado à questão da consciência 
ambiental, que é estruturada, na atualidade, sobre fatos reais e confiáveis, que neste estudo em particular ficou expresso para a maioria dos sujeitos, através da problemática dos resíduos sólidos. Esta formação, de uma consciência ambiental cidadã e participativa sensível, relaciona-se, predominantemente, ao conhecimento adquirido por meio do saber do ambiente e pela relação com a transformação e utilização dos resíduos sólidos.

Para estes separadores de resíduos, existe uma compreensão da potencialidade que este entorno geográfico, o ambiente para eles, tem quando se torna adequado à vida em comunidade, a partir da sua disponibilidade em condições de limpeza.

$\mathrm{Na}$ relação trabalho e comunidade, foram evidenciados significados apresentados pelos trabalhadores separadores de resíduos em relação a sua comunidade local, no desenvolver de suas atividades. Dentre estes significados, um aspecto importante observado foi de que os trabalhadores compreendiam que a comunidade local os classificava como sendo lixeiros e não separadores de resíduos sólidos. Este fato era considerado pelos separadores como sendo uma discriminação, pois a comunidade daquele bairro muitas vezes fazia esta associação por não relacionar que esta atividade de separação tem influência direta no meio onde vivem os próprios moradores. Neste sentido, constatou-se que a atividade de reciclagem de resíduos é considerada como sendo uma profissão degradante por parte da parcela da população, a qual não identifica estes profissionais como sendo pessoas que desempenham um papel importante dentro deste sistema econômico. Dessa forma, pode-se inferir que o separador de materiais recicláveis é incluído ao ter um trabalho, mas excluído pelo tipo de trabalho que realiza: trabalho precário, realizado em condições inadequadas, com alto grau de periculosidade e insalubridade, sem reconhecimento social, com riscos, muitas vezes, irreversíveis à saúde.

Contudo, o que necessitaria ocorrer para conseguir modificar este rótulo seria a compreensão por parte dos moradores com relação à importância de estar realizando aquela atividade de reciclagem e do quanto isto beneficia o coletivo (moradores, associados, ambiente). Este entendimento estaria associado a uma valorização da profissão dos catadores, deixando de serem vistos pela população como acumuladores de lixos. 
Porém, constatou-se, em relação à percepção de um trabalhador com a comunidade, que existem significados positivos que servem de aproximação entre os trabalhadores e a comunidade, como a questão da limpeza, pois o interesse é comum - ambiente limpo. Através desta perspectiva de limpeza, poderá ocorrer a inserção de novos sujeitos comprometidos com a importância de se estar reciclando em prol do seu ambiente, o bairro, e desta maneira contribuindo para despertar uma conscientização voltada para as questões sócio-ambientais. Através da separação dos resíduos, incluíram-se novos indivíduos para desenvolver esta atividade produtiva, a qual gera renda para eles e suas famílias e, de certa forma, modifica os significados que estas pessoas têm em relação ao resíduo, o qual passou a exercer um papel importante na sua sobrevivência. Com isto também se observa à constituição da racionalidade cultural, pois traz significações, produz a identidade integridade daquelas práticas sociais em relação ao seu ambiente geográfico.

Outro significado que surgiu associado à atividade de reciclar, apresentado pelos recicladores de resíduos, foi à questão da renda. Apresentam não só o benefício para o ambiente com a realização desta atividade, mas também do quanto à reciclagem os beneficia através da renda gerada. Pelos depoimentos, compreende-se que através desta atividade, existe a possibilidade de conseguir ganhar algum dinheiro, ajudando tanto o associado quanto o sustento da sua família. Contudo, observou-se certo descontentamento por parte dos recicladores em não poderem realizar a reciclagem de resíduos no antigo local, o lixão municipal. Neste local, o lixão, a perspectiva de coletarem um volume maior de resíduos e, conseqüentemente, obterem uma renda maior é uma realidade. Conforme seus depoimentos, com a volta da atividade ao lixão, estariam favorecendo não somente os trabalhadores da atual associação, mas contemplaria outras pessoas do bairro, como novos separadores, e também favoreceria o comércio local, através da circulação de dinheiro proveniente da atividade de reciclagem. Sem esquecer que, após o fechamento do lixão municipal, muitos que dependiam da reciclagem, não conseguiram outro emprego, sendo um dos motivos à baixa escolaridade, em virtude disso acabaram se envolvendo em atos ilegais, e alguns foram presos. Desta maneira, deixaram de sustentar seus familiares, agravando mais a situação de pobreza naquela comunidade. Esta volta da atividade de reciclagem no lixão municipal, segundo os entrevistados, não seria de qualquer maneira. Eles relatam 
que possuem um projeto, o qual mostra onde funcionaria a usina de reciclagem, e que inclusive tentaram mostrar para a prefeitura, mas que a mesma não aceitou.

Outro aspecto interessante, surgido dos separadores de resíduos, foi de que a associação estaria disposta a ajudar a comunidade local na forma de união. Isto poderia possibilitar a constituição de uma gestão ambiental participativa, pois propõe, além da oportunidade de reverter os custos ecológicos, neste caso o montante de resíduos acumulados e sem reutilização no lixão municipal, e os custos sociais, apresentados aqui como o desemprego, roubos, analfabetismo, apresenta a possibilidade de integrar a população marginalizada num processo de produção para satisfazer suas necessidades fundamentais, aproveitando o potencial ecológico de seus recursos ambientais, respeitando suas identidades coletivas. Neste aspecto, é imprescindível que exista uma forma de comunicação realmente eficaz, a fim de debater as questões inerentes àquela comunidade, que neste caso estariam relacionadas à reciclagem dos resíduos, pois além de proporcionar uma reutilização daquilo que seria posto fora, podendo agredir e contaminar o ambiente, afetando diretamente a comunidade local, venha a contribuir para fornecer uma forma de renda àquelas pessoas desempregadas, que, pela falta de uma perspectiva de conseguir outro emprego, dependiam exclusivamente da separação de resíduos, deparando-se com situações de miserabilidade, e, conseqüentemente, sujeitos a cometer atividades criminosas.

Já para a categoria da Racionalidade Instrumental, compreendida como aquela que requer instrumentos técnicos os quais traduzem os propósitos do desenvolvimento sustentável em ações, programas, mobilizando os sujeitos para promover as mudanças políticas e sociais que permitam a emergência e operatividade desta racionalidade, averigou-se que uma parte destes trabalhadores entrevistados, não realiza nenhuma atividade de divulgação. Isto pode ser devido ao fato de existir certa insatisfação por parte de um dos associados em relação aos constituintes da igreja local, visto que não existe um diálogo efetivo que possa mobilizar mudanças com relação à questão dos resíduos. Também se evidenciou que a própria associação de bairro não estabelece nenhum vínculo com a associação dos recicláveis, que na percepção do separador, pode ser em decorrência das últimas eleições para a presidência do bairro, quando os trabalhadores da reciclagem montaram uma chapa para concorrerem com a atual. 
Desta maneira, não existindo um diálogo que possa englobar mais pessoas torna-se muito difícil a constituição da racionalidade instrumental.

Neste sentido, constatou-se que as reuniões, realizadas pela outra parte dos associados, estavam mais direcionadas aos próprios separadores do que para a comunidade local. Nestas reuniões, eram debatidas questões voltadas para a comercialização dos reciclados e a divisão dos lucros entre os associados, obtidos pela venda. Não existem assembléias incentivando a participação da comunidade para contribuir com a reciclagem dos resíduos. Quando realizam alguma atividade para com a comunidade, geralmente é para doar acessórios, como sapatos, e mesmo assim são os próprios separadores que decidem e entregam para as pessoas que eles compreendem necessitar daquele utensílio. Deixa de acontecer, neste momento, uma oportunidade para ocorrer à conscientização ambiental naqueles moradores, demonstrando do quanto à reciclagem estaria beneficiando não somente os trabalhadores da reciclagem, mas principalmente o meio ambiente de todos.

Um dos motivos atribuídos a não realização de reuniões voltadas para a comunidade, possuindo um caráter informativo para a conscientização de novos sujeitos da importância da reciclagem, está associado à questão de que, conforme depoimentos, esta associação (ASTARR) é a única dentre todas do município que não obteve nenhum incentivo financeiro por parte da secretaria do meio ambiente. Além disso, constataram-se que alguns associados não se sentiam seguros e preparados para abordar questões relacionadas a resíduos, reciclagem e ambiente. Um caminho levantado por um dos trabalhadores foi à presença dos responsáveis pela secretaria do meio ambiente para proferir palestras para os associados e a comunidade. Salienta-se que, além destes profissionais, professores e estudantes da FURG poderiam participar destas palestras a fim de contribuir com estas informações. Para tanto, necessitar-se-ia de um diálogo entre as partes envolvidas para que se pudesse discutir sobre a reciclagem, esclarecer dúvidas, trocar idéias, enfim, obter um canal que servisse de suporte e apoio na divulgação do trabalho realizado pelos separadores de resíduos perante a comunidade local.

No entanto, mesmo sendo difícil de conseguir apoio, seja este da própria comunidade ou da secretária do meio ambiente, surge entre alguns entrevistados, 
uma maneira de concretizar este caminho voltado à conscientização destes moradores que é o processo denominado como pedagógico ambiental.

Este processo pedagógico ambiental torna-se um caminho viável e eficiente, pois está se perpetuando através das escolas e dos estudantes da localidade. Evidenciou-se, pelos depoimentos dos entrevistados, que as visitas realizadas à reciclagem pelos escolares, foram positivas, visto que conseguiram abordar questões inerentes relacionadas à atividade da reciclagem e desta para o ambiente. Com isto, conseguiriam realizar um diálogo, oportunizando a estas crianças conhecer mais sobre a necessidade de sempre reciclar os resíduos, obtendo-se, desta forma, uma divulgação de saberes que pode ser disseminada a muitas outras pessoas, transpassando os muros daquele bairro e englobando um maior número de sujeitos.

Além das orientações aos escolares, outra iniciativa relatada pelos entrevistados, considerada como sendo uma maneira de abordar questões sobre a reciclagem, e que se torna efetiva para a inclusão de outros sujeitos comprometidos com a preservação de seu ambiente, seriam as aulas de reforços proferidas pelos próprios separadores para aquelas crianças. $O$ aspecto que torna este caminho muito enriquecedor, para a formação das crianças, refere-se aos livros e revistas, utilizadas para as aulas, pois são provenientes da separação dos resíduos. Tornando-se, assim, uma oportunidade de conscientizar os alunos da importância da reciclagem, do quanto ela beneficia, não somente o meio ambiente, mas também o meio educacional, proporcionando acesso ao conhecimento além do âmbito escolar. Por fim, na terceira categoria, a qual engloba aspectos das relações entre trabalho e saúde, ficou evidente, através dos depoimentos e também das observações, que existe um total descuido por parte dos trabalhadores em realizar esta atividade sem a utilização de todos os equipamentos de proteção. Apesar de ser relatado que a utilização dos EPIs é uma conduta obrigatória no desenvolver do trabalho da separação, sob a pena de ser excluído da associação, somente um separador utilizava as luvas como proteção. A não utilização destes equipamentos pode estar associada ao fato de que, segundo os trabalhadores, o fornecimento dos mesmos seria obrigação da prefeitura municipal, que, no entanto não estava fazendo. Desta forma, a compra destes equipamentos depende exclusivamente dos associados, tornando mais difícil de concretizar, favorecendo desta forma a ocorrência de 
acidentes de trabalho. Nesse sentido, com relação aos riscos presentes na atividade de separação, foi identificado que estes estão relacionados pelos trabalhadores, a materiais potencialmente perigosos para sua saúde, como vidros, agulhas de injeções, lâmpadas fluorescentes, odor desagradável oriundo dos materiais recicláveis e também através da presença de animais como ratos, pulgas e baratas. Além de constatados, neste estudo, acidentes de trabalho com ferimentos em quatro associados em decorrência da manipulação de material perfurocortante como o vidro, somente um separador procurou atendimento de saúde para avaliar seu ferimento. É muito preocupante, pois uma lesão no organismo pode levar a desencadear manifestações patológicas, as quais podem ser desde uma incapacitação temporária até a morte da pessoa.

Dentre as melhorias levantadas pelos trabalhadores para sua saúde no desenvolver de seu trabalho, percebeu-se que uma destas seria a participação efetiva da prefeitura, contribuindo para ajudar mais a associação, no sentido de fornecer inseticidas para os roedores, baratas e pulgas e também construindo um depósito apropriado para o armazenamento das lâmpadas fluorescentes. Ainda referiram que uma maneira de melhorar seu trabalho e, conseqüentemente, a sua saúde, seria que todos os resíduos recicláveis já chegassem separados de acordo com sua classificação. Contudo, alguns separadores compreenderam que não haveria nada o que se fazer para modificar seu local de trabalho. É importante salientar que estas melhorias propostas por estes entrevistados são relevantes e necessárias, e além destas, deveria estar presente o uso dos EPIs, que são essenciais, principalmente nesta atividade específica, pois assegura melhor proteção a todos contra possíveis ferimentos, oriundos da separação dos resíduos.

$\mathrm{Na}$ questão que se refere à mudança necessária na comunidade para garantir uma melhor saúde a todos, observou-se que a maioria dos entrevistados relatou que a mudança necessária seria manter os pátios das casas e de terrenos baldios sem o acúmulo de resíduos. Outro grupo considerou importante modificar, na comunidade, o atendimento de saúde prestado na unidade básica de saúde. Apenas um entrevistado declarou, em seu depoimento, que deveria haver mais divulgação, em forma de propaganda, em relação à importância da reciclagem para os moradores do bairro. 
Diante este estudo, verificou-se que mesmo estes trabalhadores tendo a percepção de que a comunidade local os considera como lixeiros e não como trabalhadores da separação de resíduos, existem significados positivos que podem servir de aproximação entre os trabalhadores e a comunidade que é a questão da limpeza, pois o interesse é comum - ambiente limpo. Através desta aproximação, é que poderá surgir diálogo voltado tanto para a questão da importância de se realizar a reciclagem e do quanto esta profissão é fundamental, perante os moldes deste sistema econômico capitalista vigente na atualidade.

Além da questão da renda que esta atividade favorece a estes trabalhadores, a reciclagem também desperta outros significados como o de zelo pelo ambiente, a preservação das plantas, do desmatamento, da não contaminação dos solos e da prevenção do surgimento de certas doenças. Contudo, antes que se possa ocorrer uma conscientização ambiental da comunidade, faz-se necessário que estes trabalhadores desempenhem suas atividades de forma segura, com proteção, pois antes de tentar preservar a saúde do ambiente, é preciso que seja garantida a saúde destes trabalhadores.

Acredita-se que estas mudanças podem ser alcançadas por estes trabalhadores, desde que se tenha colaboração e comprometimento de várias entidades, como a prefeitura municipal disponibilizando recursos financeiros e materiais, implementando e avaliando a coleta seletiva no município, a associação do bairro, comprometida na divulgação da importância da reciclagem, e principalmente educadores ambientais, como os do Programa de Pós Graduação em Educação Ambiental da Universidade Federal de Rio Grande. Através deste estudo, o qual apresentou um pouco da atividade de separação dos trabalhadores de resíduos recicláveis, compreendendo seu trabalho e deste associado ao ambiente e a saúde, pode-se constatar que estes trabalhadores identificam que o seu trabalho está intimamente associado às questões sócio-ambientais, como poluição, desmatamentos, geração de renda, inclusão social, saúde e educação. Contudo, um diálogo efetivo entre estes trabalhadores e os moradores locais para que se possa concretizar uma conscientização ambiental sobre a importância de realizar a reciclagem de resíduos está se iniciando, através das aulas de reforço disponibilizadas aos alunos. Este estudo não se esgota neste momento, ele abre caminhos para que eu, ou outros pesquisadores comprometidos com a questão 
ambiental e social, possa fazê-lo, contribuindo dessa forma para melhorar significativamente os aspectos de saúde, renda e ambiente. 


\section{REFERÊNCIAS}

ADRIOLI, A. I. Cooperativismo: uma resistência à exclusão. In: Revista Espaço Acadêmico, Ano II, n¹9 dez. 2002, mensal; ISSN 1519.6186.

ALMEIDA, O. Lixo Municipal: Manual de Gerenciamento Integrado do Lixo. IPT/CEMPRE, São Paulo: 2000.

ANTUNES, R. A Dialética do trabalho. Editora Expressão Popular, São Paulo/SP: 2004, p. 200.

BARANDAS, A.P.M.G. Estudo do processamento de pilhas usadas. Rio de Janeiro: UFRJ, 2000.

BRASIL. Ministério da Saúde. Conselho Nacional de Saúde. O desenvolvimento do Sistema Único de Saúde: avanços, desafios e reafirmação dos seus princípios e diretrizes. Brasília: 2002.

CAVAlCANTE, S.; FRANCO, M. F. A. Profissão perigo: percepção de risco à saúde entre os catadores do Lixão do Jangurussu. v. VI. n. 1 Fortaleza: Revista Malestar e Subjetividade, mar/2007, p.211-231.

CARVALHO, I. C. M. Educação ambiental: a formação do sujeito ecológico. São Paulo: Cortez, 2004.

CASTIEL, L. D. Saúde Pública. Departamento de Epidemiologia e métodos quantitativos em saúde da Escola Nacional de Saúde Pública-ENSP. Disponível em: <http://www.ensp.fiocruz.br>. Acesso em: 14 de maio de 2008.

CONCEIÇÃO, C.O. Contaminação dos aterros urbanos por metais pesados no município de Rio Grande-RS. Fundação Universidade Federal do Rio Grande pósgraduação em oceanografia física, química e geológica. Dissertação de Mestrado, Rio Grande, 2005.

DEMAJOROVIC, J. et al. Os desafios da gestão compartilhada de resíduos sólidos face à lógica de mercado. In: Pedro Jacobi; Lucia da Costa Ferreira. (Org.). Diálogos em ambiente e sociedade no Brasil. 1 ed. São Paulo: Annablume, 2006, p. 456.

EIGENHEER, E. M. Lixo e Vanitas: Considerações de um Observador de resíduos. Niterói: UFF, 2003.

ENCICLOPÉDIA DE PRAGAS URBANAS. Luiz/SP: 2003.

FEITOSA, D. A. O Cuidado como Elemento Constituinte da Atividade de Separação de Resíduos Sólidos Urbano. III Encontro da ANPPAS, 23 a 26 de maio de 2006, Brasília/DF. 
FERREIRA J. A.; Anjos, L. A. Aspectos de saúde coletiva e ocupacional associados à gestão dos resíduos sólidos municipais. Cad Saúde Pública, 2001.

FERREIRA, S. L.: Os “Catadores do Lixo" na construção de uma nova cultura: a de separar o lixo e da consciência ambiental, Disponível em: <http://www.uem.br/ urutagua/007/07ferreira.htm>, 2004. Acesso em: 17 agosto de 2006.

FORATTINI, O. P. Reemergência de infecções. Revista de Saúde Publica, 2000.

FUNDAÇÃO Instituto Brasileiro de Geografia e Estatística (ibge). Pesquisa Nacional por Amostras de Domicílios 1999. Microdados. Disponível em: <http://www.ibge.gov.br/ibge.caovida/indicadoresminimos/tabela3.shtm>, 2002. Acesso em: 20 abril de 2006.

GESTÃO AMBIENTAL, boletim n. 15, maio/junho 2003. Centro de Referência em Gestão Ambiental para Assentamentos Humanos; Apliquim.

GONÇALVES, P. Os catadores de Resíduos Sólidos no Brasil. Disponível em: <http://www.lixo.com.br>. Acesso em: 3 de março 2007.

GONÇALVES, R. S. Catadores de materiais recicláveis: Trabalhadores fundamentais na cadeia de reciclagem do país. Serviço Social e Sociedade, 2005. p. 87-109.

Catadores de materiais recicláveis: estudo de suas trajetórias de vida, trabalho e saúde. Rio de Janeiro, 2004. Projeto de Dissertação (Mestrado em Saúde Pública) - Fundação Oswaldo Cruz, Rio de Janeiro, 2004.

Globalização e Desnacionalização. Rio de Janeiro: Paz e Terra, 1999.

HOUAISS, A. Dicionário da Língua Portuguesa. Editora Objetiva, 2001.

JUNCÁ, D.C.M.; Gonçalves, M.P.; Azevedo, V.G. A mão que obra no lixo. Niterói: UFF, 2001.

LEAL, A.C. et al. A reinserção do lixo na sociedade do capital: uma contribuição ao entendimento do trabalho na catação e na reciclagem. São Paulo: Revista Terra Livre, 2002, p. 177-190.

LEFF, E.. A geopolítica da biodiversidade e o desenvolvimento sustentável: economização do mundo, racionalidade ambiental e reapropriação social da natureza, cap. 1. In Martins, R.C., Valêncio, N.F.L.S. Uso e Gestão dos Recursos Hídricos no Brasil. v. 2. São Paulo: Editora Rima, São Carlos, 2003, p. 307.

LEFF, E. Saber ambiental: sustentabilidade, racionalidade, complexidade e poder. Petrópolis/RJ: Vozes, 2001.

LEI FEDERAL n. 8.080, de 19 de setembro de 1990. Dispõe sobre as condições para a promoção, proteção e recuperação da saúde, a organização e funcionamento 
dos serviços correspondentes e dá outras providências. Diário Oficial da União 1990; 19 set.

LESSA, C. Os ovos da serpente (Prefácio). In: BURSZTYN, Marcel et al. (Org.). No meio da rua: nômades, excluídos e viradores. Rio de Janeiro: Garamond, 2000.

LOGAREZZI, A. Contribuições conceituais para o gerenciamento de resíduos sólidos e ações de educação ambiental. cap. 5 . In: Leal, A.C. Resíduos Sólidos no Pontal do Paranapanema. Presidente Prudente, São Paulo: Editora Antonio Thomaz Junior, 2004, p. 276.

MAGERA, M. Os empresários do lixo: um paradoxo da modernidade. Campinas/SP: Átomo, 2003.

MANCINI, P. J. P. Uma avaliação do sistema de coleta informal de resíduos sólidos recicláveis no município de São Carlos, S.P. Dissertação de mestrado. São Carlos/SP: Escola de Engenharia de São Carlos - USP, 1999.

MARINHO, M. C. N. As transformações no mundo do trabalho e suas implicações na formação do executivo. Universidade Católica de Goiás, Dissertação de Mestrado não publicada, Mestrado em Psicologia. Goiânia, GO, 2005.

MARIUZZO, P. Lixo que vira renda. Inovação Uniemp, Campinas, v. 3, n. 6, $2007 . \quad$ Disponível em: $<$ http://inovacao.scielo.br/scielo.php?script=sci_arttext\&pid=S1808239420070006000 25\&lng=es\&nrm=iso>. Acesso em: 28 Jul. 2008.

MARX, K. O capital, Livro I, capítulo VI (inédito). In: ANTUNES, Ricardo (Org.). A Dialética do Trabalho. São Paulo: Expressão Popular, 2004.

MEDEIROS, L. F. R.; MACEDO, K.B.. Profissão: catador de material reciclável, entre o viver e o sobreviver. Revista Brasileira de Gestão e Desenvolvimento Regional; G\&DR. v. 3, n. 2, 2007, p. 72-94.

MIGUELES, C. P. Significado do lixo e ação econômica - a semântica do lixo e - trabalho dos catadores do Rio de Janeiro. Em Encontro Nacional da Associação Nacional de Pós-graduação em Pesquisa em Administração Curitiba/PR: ENANPAD, 2004.

MINAYO-GOMEZ, C.; THEDIM-COSTA, S.M.F. Precarização do trabalho e desproteção social: desafios para a saúde coletiva. In: Ciência e Saúde Coletiva, v. 4 (2), 1999.

MINAYO, M. C. S. et al. Pesquisa Social: Teoria, Método e Criatividade. 14. ed. Petrópolis: Vozes, 1999, p. 80.

BRASIL, Ministério da Saúde. Série A. Normas e Manuais Técnicos 1. ed. 1985; 2. ed. 1986; 3. ed. 1992; 4. ed. 1998; 5. ed. $20026^{a}$ edição ampliada - 2005 - Tiragem: 2.000 exemplares. 
MIURA, P. C. O. Tornar-se catador: uma análise psicossocial. Dissertação de mestrado não publicada, Mestrado em Psicologia Social, orientadora Dra. Bader Sawaia, Pontifícia Universidade Católica de São Paulo. São Paulo/SP, 2004.

OLIVEIRA, S. Gestão dos resíduos sólidos urbanos na Microrregião Homogênea Serra de Botucatu - Caracterização física dos resíduos sólidos domésticos na cidade de Botucatu/SP. 1998. Disponível em: <http://www.unilivre.org.br/centro/textos/forum/botucatu.htm>. Acesso em: 16 julho de 2007.

OLIVEIRA, W. E. Saneamento do lixo. In: Universidade de São Paulo. Faculdade de higiene e saúde pública. Lixo e limpeza pública. São Paulo: USP/OMS/OPS, cap.1, 1969.

OPAS. Programa de Preparativos para Situaciones de Emergencia y Coordinación del

SOCORRO EN CASOS DE DESASTRE. Desastres: preparativos y mitigación en las Américas, Boletín 80, Costa Rica, 2000.

PÁDUA, E. M. M. de. Metodologia da pesquisa: abordagem teórico-prática. 10. ed. rev. e atual. Campinas/SP: Papirus, 2004.

PINHEIRO, J. Q. Psicologia Ambiental brasileira no início do século XXI. Sustentável? In O. H. Yamamoto \& V. V. Gouveia (Orgs.), Construindo a psicologia brasileira: Desafios da ciência e da prática psicológica (pp. 279-313). São Paulo: Casa do Psicólogo, 2003.

PORTO, M. F. S. Análise de riscos nos locais de trabalho. São Paulo: Fundacentro, 2000.

PORTO, M. F. S. et al. Lixo, trabalho e saúde: um estudo de caso com catadores em um aterro metropolitano do Rio de Janeiro. Brasil. Cad Saúde Pública, 2004.

RANCURA, S. Aspectos ecológicos e sociais da coleta informal de resíduos urbanos do município de São Carlos - SP. Dissertação (Mestrado), Universidade Federal de São Carlos - UFSCar. São Carlos/SP, 2005, p. 98.

REGO, R.C.F. et al. $\mathbf{O}$ que é lixo afinal? Como pensam as mulheres residentes na periferia de um grande centro urbano. Cad Saúde Pública, 2002.

REIGOTA, M.; NOAL, F. O. (orgs.). Tendência da educação ambiental brasileira. 2. ed. Santa Cruz do Sul: EDUNISC, 2002.

RIGOTTO, R. Produção, consumo, saúde e ambiente. In M. C. S. Minayo \& A. C. M. Miranda (Orgs.), Saúde e ambiente sustentável: Estreitando nós Rio de Janeiro: Fiocruz, 2002, p. 233-260.

RODRIGUES, J. C. O corpo na história. Cad. Saúde Pública, Rio de Janeiro, v. 16, n. 2, $2000 \quad$ Disponível em: <http://www.scielo.br/scielo.php?script=sci_arttext\&pid=S0102311X2000000200029 
\&lng=\&nrm=iso $>$. Acesso em: 02 de novembro 2007. doi: 10.1590/S0102$311 \times 2000000200029$.

ROTH, B.W.; ISAIAS, E. M. B.; ISAIA, T. Destinação final dos resíduos sólidos urbanos. Revista Ciência \& Ambiente, Editora da UFSM, 1999. v. 1, n. 18: p. 25-40.

ROUQUAYROL, M.Z.; ALMEIDA, N.F. Epidemiologia e Saúde. 6. ed. Rio de Janeiro: Medsi, 2003.

SAMAJA, J., 2000. A Reprodução Social e a Saúde: Elementos Metodológicos sobre a Questão das Relações entre Saúde e Condições de Vida. Salvador: Editora Casa da Qualidade.

SISINNO, C.L.S., Oliveira, R.M, organizadores. Resíduos sólidos, ambiente e saúde: uma visão multidisciplinar. Rio de Janeiro: Editora Fiocruz, 2000.

SPOSATI, A. Políticas sociais nos governos petistas. Em I. Magalhães, L. Barreto \& V. Trevas (Orgs.), Governo e cidadania: balanço e reflexões sobre o modo petista de governar. São Paulo: Fundação Perseu Abramo, 1999, p. 82-107.

UNICEF. A Coleta Seletiva em Debate. Disponível em: <http://www.unicef.org/brazil/lixoecidadania/Files/m_coletaSeletiva/Coleta\%20Seletiv a.doc> Acesso em: 11 de outubro de 2007.

VELLOSO, M. P. Os catadores de lixo e o processo de emancipação social. Ciência e saúde coletiva, Rio de Janeiro 2008. Disponível em: $<$ http://www.scielo.br/scielo.php?script=sci_arttext\&pid=S1413-

$81232005000500008 \&$ Ing=pt\&nrm=iso>. Acesso em: 23 Mar 2008. doi: $10.1590 / \mathrm{S} 1413-81232005000500008$

VELLOSO, M. P. Percepções sobre resíduos resultantes da atividade humana. Revista eletrônica de jornalismo científico, 2004 . Disponível em: $<$ http://www.comciencia.br/comciencia/?section=8\&edicao=32\&id=375.>

VELASCO, S. L. Ética para o século XXI: rumo ao ecomunitarismo. São Leopoldo: Editora Unisinos, 2003.

VIANA, N. Catadores de lixo: renda familiar, consumo e trabalho precoce. Revista Estudos da Universidade Católica de Goiás, 2000, p. 407-691.

$<$ http://www.ministeriodotrabalho. gov.br>

$<$ http://pt.wikipedia.org/wiki/Chorume>

$<$ http://www.al.rs.gov.br/legis4> 
APÊNDICE 


\section{APÊNDICE 1 - Questionário}

\section{Questionário utilizado para realizar as entrevistas com os separadores}

1) Dados de identificação:
a) Nome:
b) idade:
c) sexo:
d) escolaridade:
e) profissão:
f) quantos filhos:

2) Como você se sente realizando este trabalho?

4) Você considera importante este trabalho? Por quê? Como você visualiza a importância de seu trabalho?

5) Como a comunidade local enxerga este trabalho desenvolvido por vocês?

6) Como você relaciona o seu trabalho e o meio ambiente?

7) A tua comunidade costuma se reunir para discutir seus problemas? Você poderia descrever os motivos dessas reuniões?

8) Como você costuma orientar a comunidade local quanto à importância da separação do lixo?

9) Quais os equipamentos de proteção individual que você utiliza?

10) Como você descreveria os perigosos/riscos para a sua saúde ao desenvolver o seu trabalho? Por quê?

11) Você já se feriu realizando a seleção dos materiais recicláveis?

12) A quem recorre quando apresenta algum ferimento?

13) Quais os procedimentos realizados depois de ocorrido o acidente no trabalho?

14) O que você mudaria no seu trabalho para melhorar a sua saúde?

15) O que mudaria na sua comunidade para melhorar a sua saúde?

16) Você gostaria de comentar algo mais? 
ANEXO 


\section{Anexo 1 - Termo de consentimento livre e esclarecido \\ UNIVERSIDADE FEDERAL DO RIO GRANDE PROGRAMA DE PÓS-GRADUAČ̃O EM EDUCACÃO AMBIENTAL MESTRADO EM EDUUCAÇÃO AMBIENTAL} $\mathrm{Eu}$,

autorizo a utilização de todas as informações fornecidas por mim tanto ao responder aos questionários, quanto ao participar da entrevista, para a execução da pesquisa intitulada: "A compreensão dos separadores de resíduos sólidos em relação ao seu trabalho, saúde e ambiente".

Esta pesquisa tem por objetivo Identificar, no coletivo dos trabalhadores, a caracterização da racionalidade instrumental e cultural no seu trabalho.

Os dados serão coletados por meio de jornadas de observação livre, com base em um acompanhamento direto e intensivo, valendo-nos de entrevistas semiestruturadas, de forma a prevalecer à espontaneidade e à informalidade durante as conversas, bem como a não indução de respostas. Para melhor compreender a situação em estudo, utilizará também de um diário de campo, no qual se registrará todos os fatos considerados relevantes não colhidos pelas técnicas utilizadas. Essas entrevistas serão gravadas, transcritas e analisadas segundo a análise de conteúdo.

Tenho conhecimento do caráter científico do estudo, no qual minha colaboração é estritamente voluntária, sendo-me assegurado o direito de retirar este consentimento em qualquer fase da investigação, sem nenhuma penalização ou prejuízo à minha pessoa.

Estou ciente de que não haverá identificação pessoal e que as informações fornecidas serão tratadas de modo sigiloso.

Também estou ciente que a minha participação como sujeito da pesquisa, através da resposta ao questionário e no momento da entrevista, ocorrerá em data e local marcado antecipadamente, de modo a não interferir desfavoravelmente na minha rotina de trabalho.

Rio Grande,

Assinatura do entrevistado:

Pesquisador/Mestrando:

Pablo Viana Stolz - Telefone: 5330256034 - e-mail: stolz@ibest.com.br

Sob orientação da Prof. Dra. Marta Regina Cezar Vaz

Programa de Pós-Graduação em Educação Ambiental - FURG - Telefone: 53 32336615 